\title{
Inhibition of corrosion of mild steel in acid media by $\mathbf{N}^{\prime}$-benzylidene-3- (quinolin-4-ylthio)propanohydrazide
}

\author{
V RAMESH SALIYAN and AIRODY VASUDEVA ADHIKARI* \\ Department of Chemistry, National Institute of Technology, Surathkal 575 025, India
}

MS received 26 November 2007; revised 15 January 2008

\begin{abstract}
In the present investigation a new corrosion inhibitor, $N^{\prime}-(3,4-d i h y d r o x y b e n z y l i d e n e)-3-\{[8-(t r i-$ fluoromethyl)quinolin-4-yl]thio\}propanohydrazide(DHBTPH) was synthesized, characterized and tested as a corrosion inhibitor for mild steel in $\mathrm{HCl}(1 \mathrm{M}, 2 \mathrm{M})$ and $\mathrm{H}_{2} \mathrm{SO}_{4}(0.5 \mathrm{M}, 1 \mathrm{M})$ solutions using weight-loss method, electrochemical impedance spectroscopy (EIS) and potentiodynamic polarization methods. The corrosion inhibition efficiency measured by all the above three techniques were in good agreement with each other. The results showed that DHBTPH is a very good inhibitor for mild steel in acidic media. The inhibition efficiency in different acid media was found to be in the decreasing order $0.5 \mathrm{M} \mathrm{H}_{2} \mathrm{SO}_{4}>1 \mathrm{M} \mathrm{HCl}>1 \mathrm{M}$ $\mathrm{H}_{2} \mathrm{SO}_{4}>2 \mathrm{M} \mathrm{HCl}$. The inhibition efficiency increases with increasing inhibitor concentration and with increasing temperature. It acts as an anodic inhibitor. Thermodynamic and activation parameters are discussed. Adsorption of DHBTPH was found to follow the Langmuir's adsorption isotherm. Chemisorption mechanism is proposed. The mild steel samples were also analysed by scanning electron microscopy (SEM).
\end{abstract}

Keywords. Activation energy; adsorption isotherms; corrosion inhibitors; mild steel; scanning electron microscopy; thermodynamic parameters.

\section{Introduction}

Acid corrosion inhibitors find vast application in the industrial field as components in acid descaling, oil well acidizing, acid pickling, acid cleaning, etc. Most of the efficient corrosion inhibitors used in industry are organic compounds having multiple bonds and hetero atoms like $\mathrm{N}, \mathrm{O}, \mathrm{S}$ through which they are adsorbed on the metal surface (Rengamani et al 1994; Abd El-Rehim et al 1999; Quraishi and Jamal 2002; Emregul et al 2003; Khaled et al 2004; Wang et al 2004; Bentiss et al 2005; Zor et al 2005). The influence of such organic compounds on the corrosion of mild steel in acidic solution has been investigated by several researchers (Quraishi et al 2002; Popova et al 2004; Vishwanatham and Anil Kumar 2005). The inhibition property of these compounds is attributed to their molecular structure (Mora-Mendoza et al 2002).

The aim of this work was to investigate the role played by newly synthesized $\mathrm{N}^{\prime}$-(3,4-dihydroxybenzylidene)-3\{[8-(trifluoromethyl)quinolin-4-yl]thio\}propanohydrazide (DHBTPH) on the corrosion behaviour of mild steel in $\mathrm{HCl}(1 \mathrm{M}, 2 \mathrm{M})$ and $\mathrm{H}_{2} \mathrm{SO}_{4}(0.5 \mathrm{M}, 1 \mathrm{M})$ solutions. The molecular design of the new compound was based on the fact that quinoline (a nitrogen heterocycle) containing trifluoromethyl group, thio, hydroxy and hydrazide groups would

*Author for correspondence (avchem@nitk.ac.in) contribute more effectively towards inhibition of corrosion of mild steel in acidic media.

In view of this, a new inhibitor, DHBTPH (2) was synthesized, characterized and the inhibitive action of it on the corrosion behaviour of mild steel in acid media was measured. Corrosion inhibition was investigated using weight-loss, electrochemical impedance spectroscopic (EIS) and potentiodynamic polarization (Tafel) methods and their results were compared.

\section{Experimental}

\subsection{Inhibitor synthesis and characterization}

A mixture of $3 \cdot 15 \mathrm{~g}(0 \cdot 01 \mathrm{~mol})$ of $3-\{[8$-(trifluoromethyl) quinolin-4-yl]thio\} propane hydrazide (1), $1.66 \mathrm{~g}$ of $3,4-$ dihydroxy benzaldehyde ( $0.012 \mathrm{~mol}), 0.2 \mathrm{~mL}$ of glacial acetic acid and $25 \mathrm{~mL}$ of dry methanol was refluxed for $8 \mathrm{~h}$. The crystalline product thus obtained was filtered, washed, dried and re-crystallized in ethanol to afford the crystals of 2 , yield $91 \%$ and m.p. $188-190^{\circ} \mathrm{C}$. The required intermediates were prepared following reported procedures (Allais et al 1969). Their purity was monitored by thin layer chromatography, and its structure was established by spectral and elemental analyses. Scheme 1 shows the synthesis sequence. The IR spectra (in $\mathrm{KBr}$ pellets) were recorded on a Thermo-Avatar spectrophotometer. Mass spectra were recorded on a Jeol JMS-D 300 operating at 

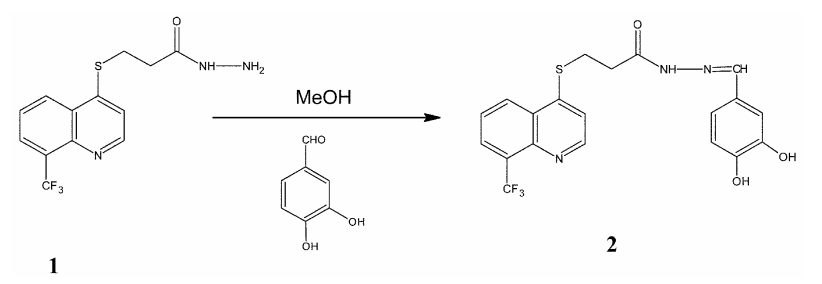

Scheme 1.

$70 \mathrm{eV}$. Thermo Electron Corporation Flash EA 1112 series $\mathrm{CHN}$ analyser was used for elemental analysis.

\subsection{Corrosion and its inhibition studies}

Mild steel specimen of chemical composition, C $0 \cdot 16 \%$, Mn $0.2 \%$, S $0.05 \%$, P $0.07 \%$, Si $0.2 \%$ and the remainder iron, in sheet form have been used for weight-loss measurements. The samples were polished with different emery papers of grades $0,1,2,3$ and 4, cleaned with acetone, washed with doubly distilled water and finally dried. For the electrochemical measurement the arrangement used was a conventional three-electrode Pyrex glass cell with a platinum counter electrode and a saturated calomel electrode (SCE) as reference. The working steel specimen cut from cylindrical rods of mild steel was covered with epoxy adhesive-Araldite, so that its cross sectional area, $0.785 \mathrm{~cm}^{2}$, was in contact with the solution. Experiments were carried out at constant temperature of $\pm 0.5^{\circ} \mathrm{C}$ using a calibrated thermostat. The solutions for all the experiments were prepared with doubly distilled water, analar grade hydrochloric acid (Merck) and sulphuric acid (Merck).

For weight-loss measurements, a clean weighed mild steel specimen in the sheet form $(2 \times 5 \times 0.05 \mathrm{~cm})$ was completely immersed at inclined position in a beaker. After $24 \mathrm{~h}$ of immersion, the electrode was withdrawn, rinsed with doubly distilled water, washed with acetone, dried and weighed. The weight-loss was used to calculate the corrosion rate (CR) in milligrams per square centimetre per hour.

EIS and Tafel polarization studies were carried out by using an electrochemical work station (Auto Lab 30, Metrohm). EIS measurements were carried out in a frequency range of $1,00,000 \mathrm{~Hz}-0.05 \mathrm{~Hz}$ using an amplitude of $10 \mathrm{mV}$, peak-to-peak using a.c. signal at the open circuit potential. The potentiodynamic current-potential curves were recorded by changing the electrode potential automatically from $-250 \mathrm{mV}$ to $+250 \mathrm{mV}$ vs OCP with a scan rate of $1 \mathrm{mV} \mathrm{s}^{-1}$. Polished mild steel specimen of $0.785 \mathrm{~cm}^{2}$ surface area was exposed to $100 \mathrm{~mL}$ of $\mathrm{HCl}(1 \mathrm{M}, 2 \mathrm{M})$ and $\mathrm{H}_{2} \mathrm{SO}_{4}(0.5 \mathrm{M}, 1 \mathrm{M})$ solutions at $30^{\circ} \mathrm{C}$ without and with various concentrations $\left(0.230 \times 10^{-4}\right.$ to $\left.11.494 \times 10^{-4} \mathrm{M}\right)$ of inhibitors. Similar experiments were carried out at $40^{\circ}$, $50^{\circ}$ and $60^{\circ} \mathrm{C}$.

The electrode surface was examined by making photographs of the surface. SEM Jeol JSM-6380 was used for this purpose.

\section{Results and discussion}

\subsection{Characterization of DHBTPH 2}

The characterization data of $\mathrm{N}^{\prime}$-(3,4-dihydroxybenzylidene)$3-\{[8$-(trifluoromethyl) quinolin-4-yl] thio\}propanohydrazide (DHBTPH, 2) are given below.

IR: (KBr) $v \mathrm{~cm}^{-1}: 3437.4$ (N-H str.), $3274(\mathrm{O}-\mathrm{H}), 2961.7$ $(\mathrm{C}-\mathrm{H}), 1654 \cdot 1(\mathrm{C}=\mathrm{O}), 1577 \cdot 7(\mathrm{C}=\mathrm{N}), 1518 \cdot 3(\mathrm{~N}-\mathrm{H}$ bending $)$, $1148 \cdot 6,1097 \cdot 8,1021 \cdot 8(\mathrm{C}-\mathrm{F}), 700 \cdot 4(\mathrm{C}-\mathrm{S})$.

MASS $\left(\mathrm{M}^{+}\right)$: The molecular ion peak $\left(\mathrm{M}^{+}\right)$appeared at 435, which corresponds to its molecular formula, $\mathrm{C}_{20} \mathrm{H}_{16} \mathrm{~F}_{3} \mathrm{~N}_{3} \mathrm{O}_{3} \mathrm{~S}$, confirming the formation of compound 2. The base peak appearing at 436 is due to protonated molecular ion peak $(\mathrm{M}+\mathrm{H})^{+}$, the presence of which confirms the structure of 2 .

Elemental analysis: Found (calcd): C, 55.25 (55.22); H, $3.69(3.71) ; \mathrm{N}, 9.68(9.66) \% ; \mathrm{C}_{20} \mathrm{H}_{16} \mathrm{~F}_{3} \mathrm{~N}_{3} \mathrm{O}_{3} \mathrm{~S}$.

\subsection{Corrosion measurement}

3.2a Weight-loss method: The weight-loss of mild steel strips in $100 \mathrm{~mL}$ of $\mathrm{HCl}(1 \mathrm{M}, 2 \mathrm{M})$ and $\mathrm{H}_{2} \mathrm{SO}_{4}(0.5 \mathrm{M}$, $1 \mathrm{M})$ solutions at $30^{\circ} \mathrm{C}$ without and with various concentrations $\left(0.230 \times 10^{-4}\right.$ to $\left.11.494 \times 10^{-4} \mathrm{M}\right)$ of inhibitors were determined after $24 \mathrm{~h}$ of immersion period. The inhibition efficiency, $\% I E$, was determined by using the following equation

$$
\% I E=\frac{W_{\text {corr }}-W_{\text {corr(inh })}}{W_{\text {corr }}} \times 100,
$$

where $W_{\text {corr }}$ and $W_{\text {corr(inh) }}$ are the corrosion rates of mild steel in the absence and presence of the inhibitor, respectively. The values of $\% I E$ and corrosion rate $(\mathrm{CR})$ obtained from weight-loss measurements for different acids and different inhibitor concentrations at $30^{\circ} \mathrm{C}$ are given in table 1 .

Corrosion inhibition efficiency increases with increasing concentration of inhibitor in all the four acid media (table 1). The corrosion inhibition efficiency trend in different acid media was in the decreasing order $0.5 \mathrm{M} \mathrm{H}_{2} \mathrm{SO}_{4}>1 \mathrm{M}$ $\mathrm{HCl}>1 \mathrm{M} \mathrm{H}_{2} \mathrm{SO}_{4}>2 \mathrm{M} \mathrm{HCl}$. The higher \%IE in $\mathrm{H}_{2} \mathrm{SO}_{4}$ than $\mathrm{HCl}$ may be due to the availability of more sites on the metal surface in $\mathrm{H}_{2} \mathrm{SO}_{4}$ solution because of the lesser adsorption of the sulphate ion on the steel surface (Bentiss et al 2001). In each acid media, maximum $\% I E$ was achieved at $11.494 \times 10^{-4} \mathrm{M}$ and a further increase in concentration did not cause any appreciable change in the performance of the inhibitor. The corrosion inhibition can be attributed to the adsorption of the inhibitor at the steel/ acid solution interface. The adsorption is mainly attributed to higher electron densities at active functional groups, present in the DHBTPH molecules (Bentiss et al 2005).

3.2b EIS method: EIS technique was also used to investigate the corrosion behaviour of mild steel in all the 
Table 1. Corrosion parameters obtained from weight-loss and electrochemical measurements of mild steel in acid media containing various concentrations of DHBTPH at $30^{\circ} \mathrm{C}$.

\begin{tabular}{|c|c|c|c|c|c|c|c|c|}
\hline \multirow[b]{2}{*}{ Acid media } & \multirow{2}{*}{$\begin{array}{c}\text { Inhibitor } \\
\text { conc. }\left(10^{-4} \mathrm{M}\right)\end{array}$} & \multicolumn{2}{|c|}{ Weight-loss } & \multicolumn{3}{|c|}{ EIS } & \multicolumn{2}{|c|}{ Polarization curves } \\
\hline & & $\mathrm{CR}\left(\mathrm{mg} \mathrm{cm}^{-2} \mathrm{~h}^{-1}\right)$ & $I E(\%)$ & $R_{\mathrm{t}}\left(\Omega \mathrm{cm}^{-2}\right)$ & $C_{\mathrm{dl}}\left(\mu \mathrm{Fcm}^{-2}\right)$ & $I E(\%)$ & $I_{\text {corr }}\left(\mu \mathrm{Acm}^{-2}\right)$ & $I E(\%)$ \\
\hline \multirow[t]{6}{*}{$1 \mathrm{M} \mathrm{HCl}$} & Blank & $2 \cdot 15$ & - & $24 \cdot 54$ & $260 \cdot 2$ & - & 570 & - \\
\hline & 0.230 & $1 \cdot 32$ & 38.5 & 37.52 & 195.2 & 34.6 & 360 & $36 \cdot 8$ \\
\hline & $1 \cdot 149$ & 1.04 & 51.7 & $47 \cdot 10$ & 145.6 & 47.9 & 287 & $49 \cdot 7$ \\
\hline & 2.299 & 0.76 & $64 \cdot 5$ & 62.44 & $130 \cdot 1$ & $60 \cdot 7$ & 213 & $62 \cdot 6$ \\
\hline & 5.747 & 0.48 & $77 \cdot 5$ & 92.26 & $115 \cdot 7$ & 73.4 & 140 & $75 \cdot 5$ \\
\hline & 11.494 & $0 \cdot 21$ & $90 \cdot 2$ & $177 \cdot 83$ & $96 \cdot 3$ & $86 \cdot 2$ & 066 & $88 \cdot 4$ \\
\hline \multirow[t]{6}{*}{$2 \mathrm{M} \mathrm{HCl}$} & Blank & $3 \cdot 87$ & - & 14.63 & $280 \cdot 9$ & - & 941 & - \\
\hline & $0 \cdot 230$ & $2 \cdot 30$ & $40 \cdot 5$ & $23 \cdot 26$ & $205 \cdot 6$ & $37 \cdot 1$ & 575 & $38 \cdot 9$ \\
\hline & $1 \cdot 149$ & $1 \cdot 83$ & $52 \cdot 6$ & 28.46 & $165 \cdot 2$ & $48 \cdot 6$ & 465 & $50 \cdot 6$ \\
\hline & $2 \cdot 299$ & $1 \cdot 37$ & $64 \cdot 6$ & $37 \cdot 61$ & $142 \cdot 3$ & $61 \cdot 1$ & 349 & $62 \cdot 9$ \\
\hline & 5.747 & $0 \cdot 92$ & $76 \cdot 2$ & $53 \cdot 20$ & $125 \cdot 1$ & $72 \cdot 5$ & 240 & $74 \cdot 5$ \\
\hline & 11.494 & $0 \cdot 53$ & $86 \cdot 4$ & $83 \cdot 13$ & $110 \cdot 8$ & $82 \cdot 4$ & 146 & $84 \cdot 5$ \\
\hline \multirow[t]{6}{*}{$0 \cdot 5 \mathrm{M} \mathrm{H}_{2} \mathrm{SO}_{4}$} & Blank & $4 \cdot 52$ & - & $12 \cdot 55$ & $240 \cdot 5$ & - & 1083 & - \\
\hline & $0 \cdot 230$ & 1.64 & $63 \cdot 7$ & $31 \cdot 38$ & 188.4 & $60 \cdot 0$ & 412 & $62 \cdot 0$ \\
\hline & $1 \cdot 149$ & $1 \cdot 36$ & $70 \cdot 0$ & $37 \cdot 13$ & $146 \cdot 8$ & $66 \cdot 2$ & 344 & $68 \cdot 2$ \\
\hline & $2 \cdot 299$ & 0.97 & $78 \cdot 6$ & $50 \cdot 20$ & $120 \cdot 3$ & $75 \cdot 0$ & 249 & $77 \cdot 0$ \\
\hline & 5.747 & 0.63 & $86 \cdot 1$ & $70 \cdot 90$ & $102 \cdot 7$ & $82 \cdot 3$ & 170 & $84 \cdot 3$ \\
\hline & 11.494 & $0 \cdot 16$ & $96 \cdot 4$ & 171.92 & $85 \cdot 6$ & $92 \cdot 7$ & 057 & $94 \cdot 7$ \\
\hline \multirow[t]{6}{*}{$1 \mathrm{M} \mathrm{H}_{2} \mathrm{SO}_{4}$} & Blank & $9 \cdot 68$ & - & $6 \cdot 18$ & $290 \cdot 6$ & - & 2138 & - \\
\hline & $0 \cdot 230$ & $4 \cdot 00$ & 58.7 & 13.83 & $205 \cdot 3$ & $55 \cdot 3$ & 915 & $57 \cdot 2$ \\
\hline & $1 \cdot 149$ & $3 \cdot 30$ & $65 \cdot 9$ & $16 \cdot 44$ & $165 \cdot 9$ & $62 \cdot 4$ & 759 & $64 \cdot 5$ \\
\hline & 2.299 & $2 \cdot 57$ & $73 \cdot 5$ & $20 \cdot 46$ & $140 \cdot 7$ & $69 \cdot 8$ & 603 & $71 \cdot 8$ \\
\hline & 5.747 & $1 \cdot 83$ & $81 \cdot 1$ & $27 \cdot 11$ & $125 \cdot 6$ & $77 \cdot 2$ & 447 & $79 \cdot 1$ \\
\hline & 11.494 & $1 \cdot 18$ & $87 \cdot 8$ & $39 \cdot 87$ & $106 \cdot 7$ & 84.5 & 291 & $86 \cdot 4$ \\
\hline
\end{tabular}

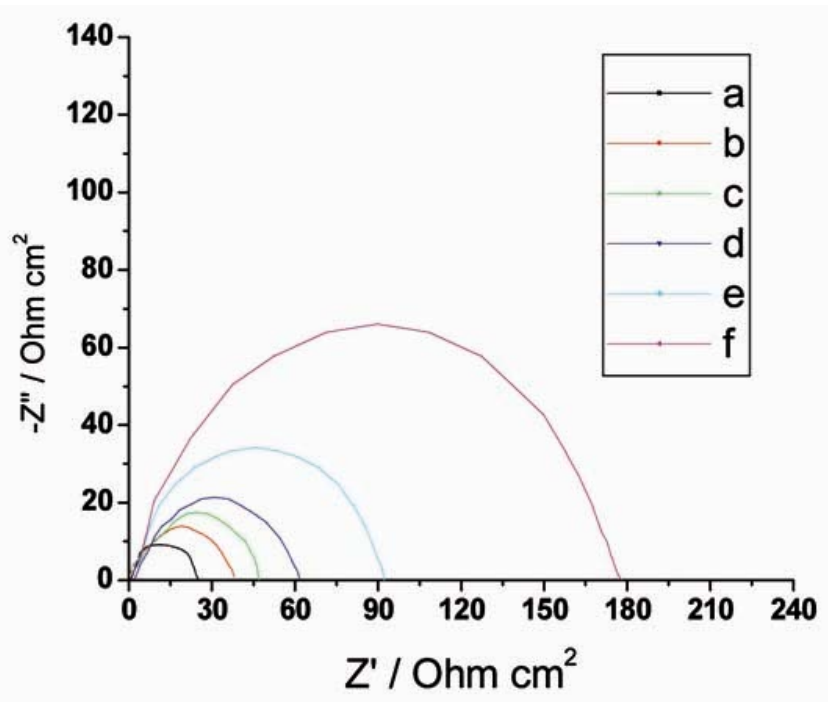

Figure 1. Complex-plane impedance of mild steel in $1 \mathrm{M} \mathrm{HCl}$ at $30^{\circ} \mathrm{C}$ in presence of different concentrations of DHBTPH: (a) 0 , (b) $0.230 \times 10^{-4}$, (c) $1.149 \times 10^{-4}$, (d) $2.299 \times 10^{-4}$, (e) $5.747 \times 10^{-4}$ and (f) $11.494 \times 10^{-4} \mathrm{M}$.

above conditions. The equivalent circuit models used to fit the experimental results were as previously reported (Abd El-Rehim et al 1999). Figures 1-4 show the complexplane impedance plots (Nyquist plots) for mild steel in

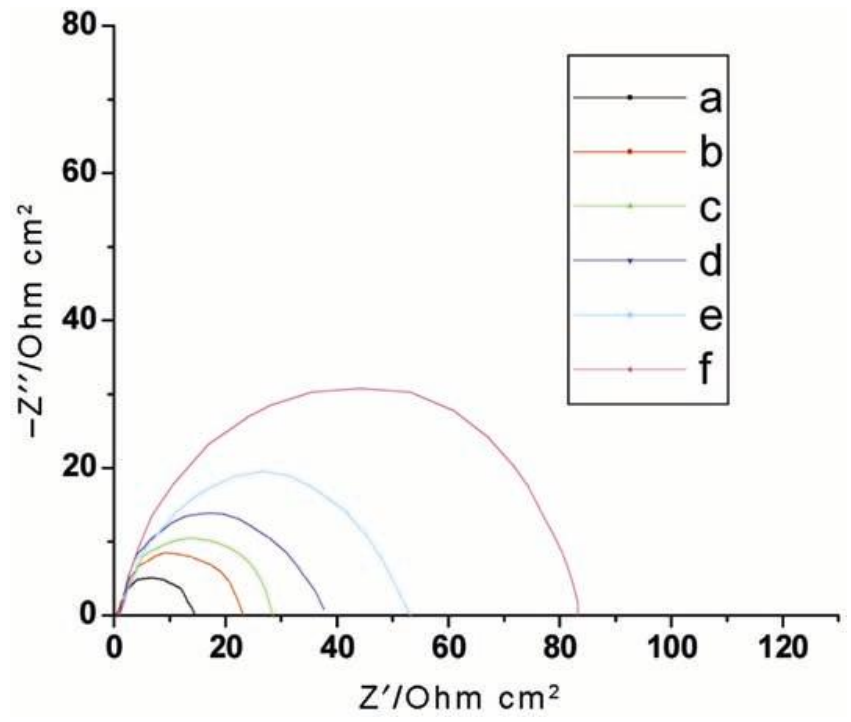

Figure 2. Complex-plane impedance of mild steel in $2 \mathrm{M} \mathrm{HCl}$ at $30^{\circ} \mathrm{C}$ in presence of different concentrations of DHBTPH: (a) 0 , (b) $0.230 \times 10^{-4}$, (c) $1.149 \times 10^{-4}$, (d) $2.299 \times 10^{-4}$, (e) $5.747 \times 10^{-4}$ and (f) $11.494 \times 10^{-4} \mathrm{M}$.

$1 \mathrm{M} \mathrm{HCl}, 2 \mathrm{M} \mathrm{HCl}, 0.5 \mathrm{M} \mathrm{H}_{2} \mathrm{SO}_{4}$ and $1 \mathrm{M} \mathrm{H}_{2} \mathrm{SO}_{4}$ without and with various concentrations of DHBTPH at $30^{\circ} \mathrm{C}$. As it can be seen from the figures, the Nyquist plots contain depressed semi-circle with the centre under the real axis, 
whose size increases with the inhibitor concentration, indicating a charge transfer process mainly controlling the corrosion of mild-steel. Such a behaviour, characteristic for solid electrodes and often refer to a frequency dispersion, has been attributed to roughness and other inhomogeneities of the solid surface (Juttner 1990; Stoynov et al 1991). It is apparent from these plots that the impedance response of mild steel in uninhibited acid solution has significantly changed after the addition of DHBTPH in the corrosive solutions. This indicated that the impedance of the inhibited substrate has increased with increasing

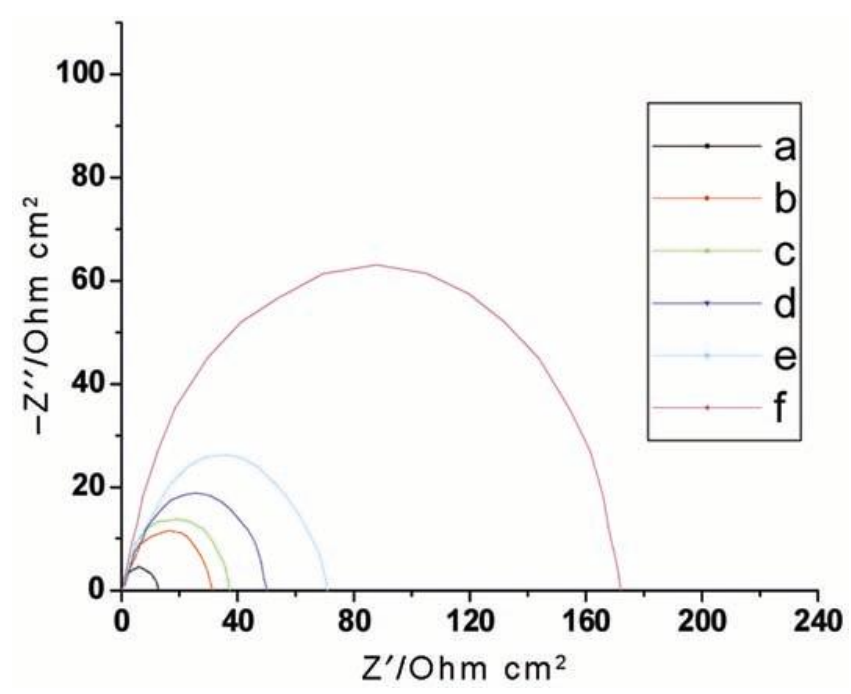

Figure 3. Complex-plane impedance of mild steel in $0.5 \mathrm{M}$ $\mathrm{H}_{2} \mathrm{SO}_{4}$ at $30^{\circ} \mathrm{C}$ in presence of different concentrations of DHBTPH: (a) 0 , (b) $0.230 \times 10^{-4}$, (c) $1.149 \times 10^{-4}$, (d) $2.299 \times$ $10^{-4}$, (e) $5.747 \times 10^{-4}$ and (f) $11.494 \times 10^{-4} \mathrm{M}$.

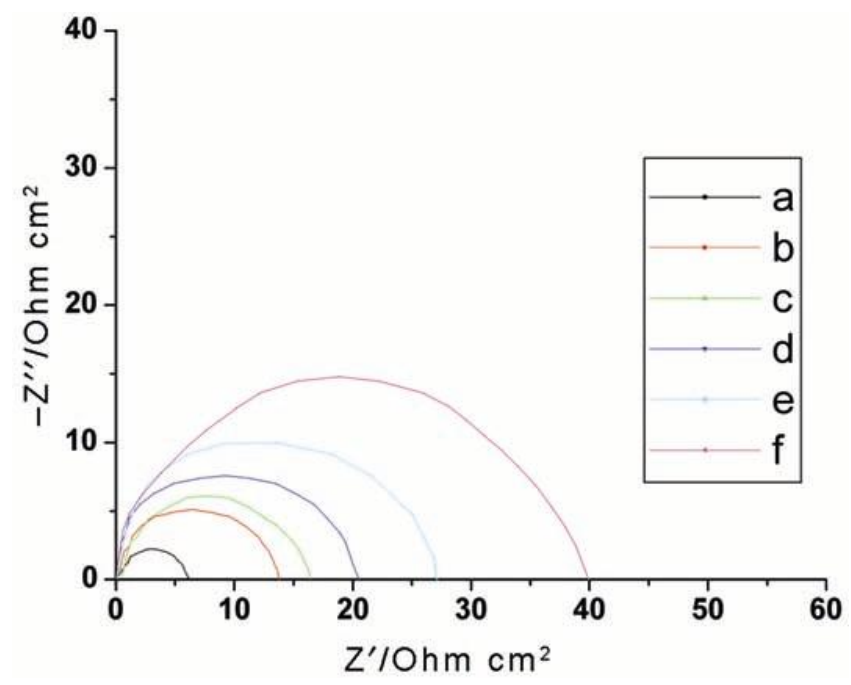

Figure 4. Complex-plane impedance of mild steel in $1 \mathrm{M}$ $\mathrm{H}_{2} \mathrm{SO}_{4}$ at $30^{\circ} \mathrm{C}$ in presence of different concentrations of DHBTPH: (a) 0 , (b) $0.230 \times 10^{-4}$, (c) $1.149 \times 10^{-4}$, (d) $2.299 \times$ $10^{-4}$, (e) $5.747 \times 10^{-4}$ and (f) $11.494 \times 10^{-4} \mathrm{M}$. concentration of inhibitor. The characteristic parameters associated to the impedance diagrams $\left(R_{\mathrm{t}}\right.$ and $\left.C_{\mathrm{dl}}\right)$ and $\% I E$ are given in table $1 . \% I E$ was calculated from the following equation

$$
\% I E=\frac{\left(\frac{1}{R_{\mathrm{t}}}\right)_{0}-\left(\frac{1}{R_{\mathrm{t}}}\right)}{\left(\frac{1}{R_{\mathrm{t}}}\right)_{0}} \times 100,
$$

where $\left(R_{\mathrm{t}}\right)_{0}$ and $\left(R_{\mathrm{t}}\right)$ are the uninhibited and inhibited charge transfer resistances, respectively (Abd El-Rehim et al 1999). The values of \%IE obtained from EIS and weightloss measurements are in sequence.

The $R_{\mathrm{t}}$ values increased with the increasing concentration of the inhibitor (table 1). On the other hand, the value of $C_{\mathrm{dl}}$ decreased with an increase in inhibitor concentration. This situation was the result of increase in the surface coverage by the DHBTPH, which led to an increase in the inhibition efficiency (table 1). The thickness of the protective layer, $\delta_{\text {org }}$, was related to $C_{\mathrm{dl}}$ by the following equation (Bentiss et al 2002)

$$
\delta_{\text {org }}=\frac{\varepsilon_{0} \varepsilon_{T}}{C_{\mathrm{dl}}},
$$

where $\varepsilon_{0}$ is the vacuum dielectric constant and $\varepsilon_{\mathrm{T}}$ the relative dielectric constant. This decrease in $C_{\mathrm{dl}}$, which can result from a decrease in local dielectric constant and/or an increase in the thickness of the electrical double layer, suggested that the DHBTPH molecules function by adsorption at the metal/solution interface. Here, the gradual replacement of water molecules by the adsorption of the organic molecules on the metal surface, decreases the extent of metal dissolution and hence it causes the change in $C_{\mathrm{dl}}$ values (McCafferty and Hackerman 1972).

Two modes of adsorption can be considered. The process of physical adsorption requires the presence of electrically charged metal surface and the charged species in the bulk of the solution. Chemisorption process involves charge sharing or charge transfer from the inhibitor molecules to the metal surface. This is possible in case of positive as well as negative charges on the surface. The presence of a transition metal, having vacant, low-energy electron orbital, and an inhibitor molecule having relatively loosely bound electrons or hetero atoms with lonepair electrons facilitates this adsorption (Reinhard and Rammet 1985; Mehaute and Grepy 1989). On the other hand, the DHBTPH, which possesses nitrogen sulphur and oxygen atoms with lone-pair electrons, can accept a proton, leading the cationic forms. These species can adsorb on the metal surface because of attractive forces between the negatively charged metal and the positively charged DHBTPH.

3.2c Tafel polarization method: As shown in figures $5-8$, both cathodic and anodic corrosion reactions of mild 
steel were inhibited with the increase of DHBTPH concentration in all corrosive solutions. DHBTPH suppressed the anodic reaction to greater extents than the cathodic one, at all concentrations. This result suggests that the addition of DHBTPH reduces anodic dissolution and also retards the hydrogen evolution reaction. Tafel lines of nearly equal slopes were obtained, indicating that the hydrogen evolution reaction was activation-controlled.

The corrosion current density $\left(I_{\text {corr }}\right)$ values are presented in table 1 . The data show that the $I_{\text {corr }}$ values de-

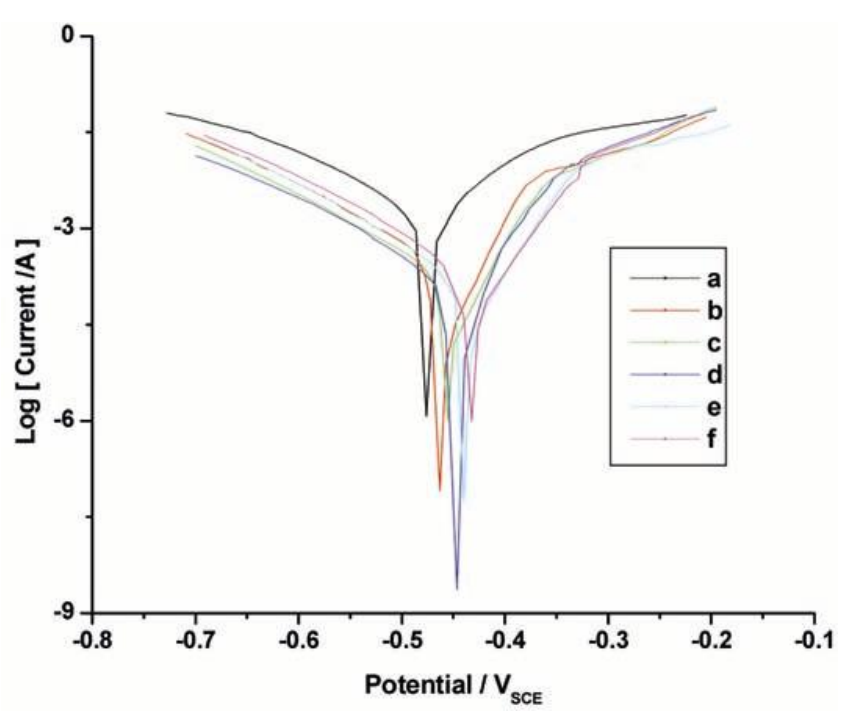

Figure 5. Polarization curves of mild steel in $1 \mathrm{M} \mathrm{HCl}$ at $30^{\circ} \mathrm{C}$ in presence of different concentrations of DHBTPH: (a) 0 , (b) $0.230 \times 10^{-4}$, (c) $1.149 \times 10^{-4}$, (d) $2.299 \times 10^{-4}$, (e) $5.747 \times$ $10^{-4}$ and (f) $11.494 \times 10^{-4} \mathrm{M}$.

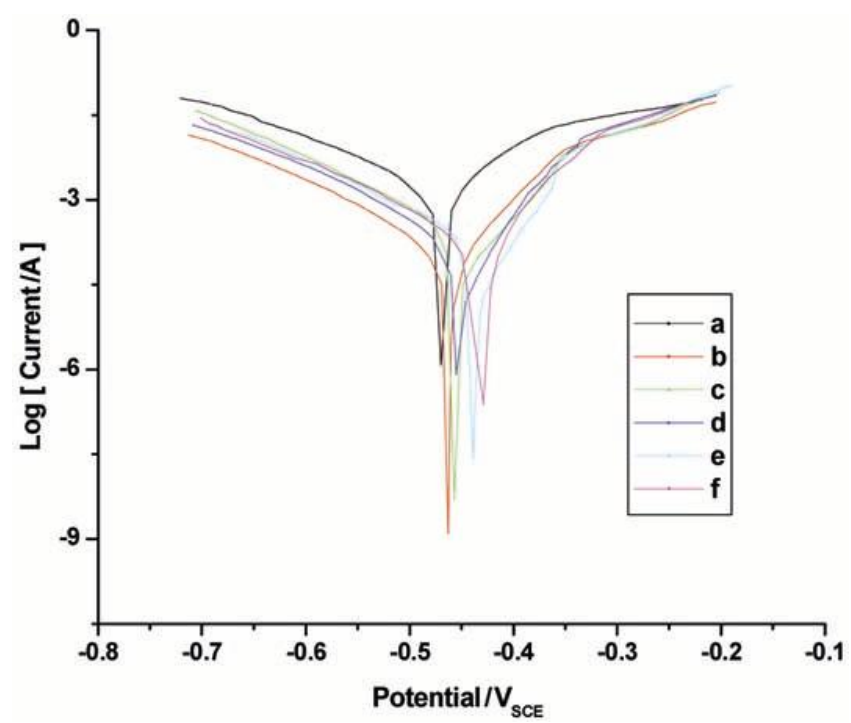

Figure 6. Polarization curves of mild steel in $2 \mathrm{M} \mathrm{HCl}$ at $30^{\circ} \mathrm{C}$ in presence of different concentrations of DHBTPH: (a) 0 , (b) $0.230 \times 10^{-4}$, (c) $1.149 \times 10^{-4}$, (d) $2.299 \times 10^{-4}$, (e) $5.747 \times$ $10^{-4}$ and (f) $11.494 \times 10^{-4} \mathrm{M}$. creased considerably in the presence of DHBTPH and decreased with increasing inhibitor concentration. The decrease in $I_{\text {corr }}$ with increasing inhibitor concentration was associated with the shift of corrosion potential, $E_{\text {corr }}$, to a less negative value. This indicates that DHBTPH suppressed anodic reaction. Corrosion inhibition efficiency was calculated using the electrochemical relation

$$
\% I E=\frac{\left[I_{\text {corr }}-I_{\text {corr(inh) }}\right]}{I_{\text {corr }}} \times 100,
$$

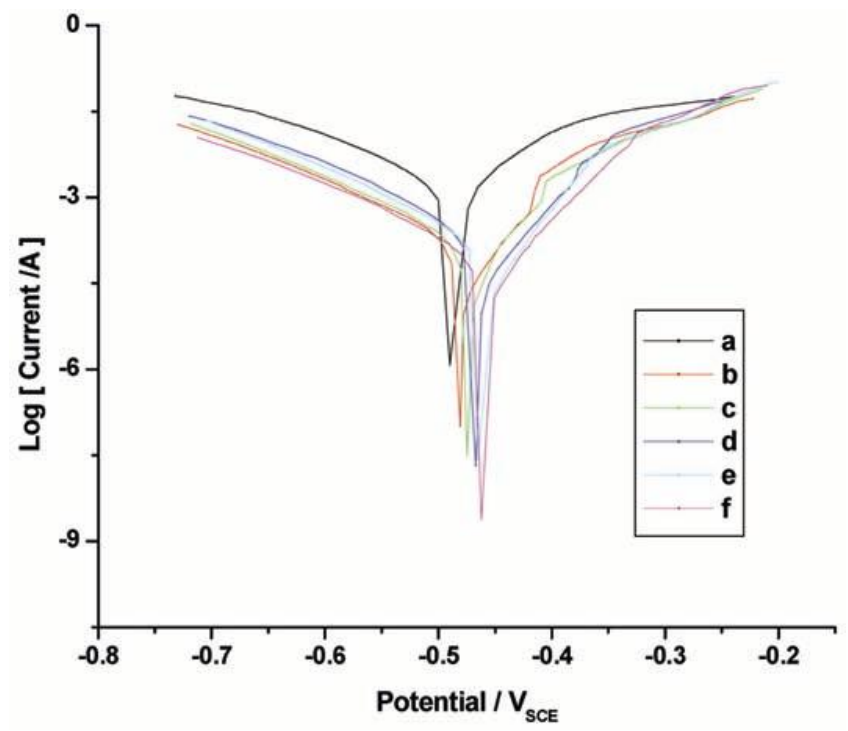

Figure 7. Polarization curves of mild steel in $0.5 \mathrm{M} \mathrm{H}_{2} \mathrm{SO}_{4}$ at $30^{\circ} \mathrm{C}$ in presence of different concentrations of DHBTPH: (a) 0 , (b) $0.230 \times 10^{-4}$, (c) $1.149 \times 10^{-4}$, (d) $2.299 \times 10^{-4}$, (e) $5.747 \times$ $10^{-4}$ and (f) $11.494 \times 10^{-4} \mathrm{M}$.

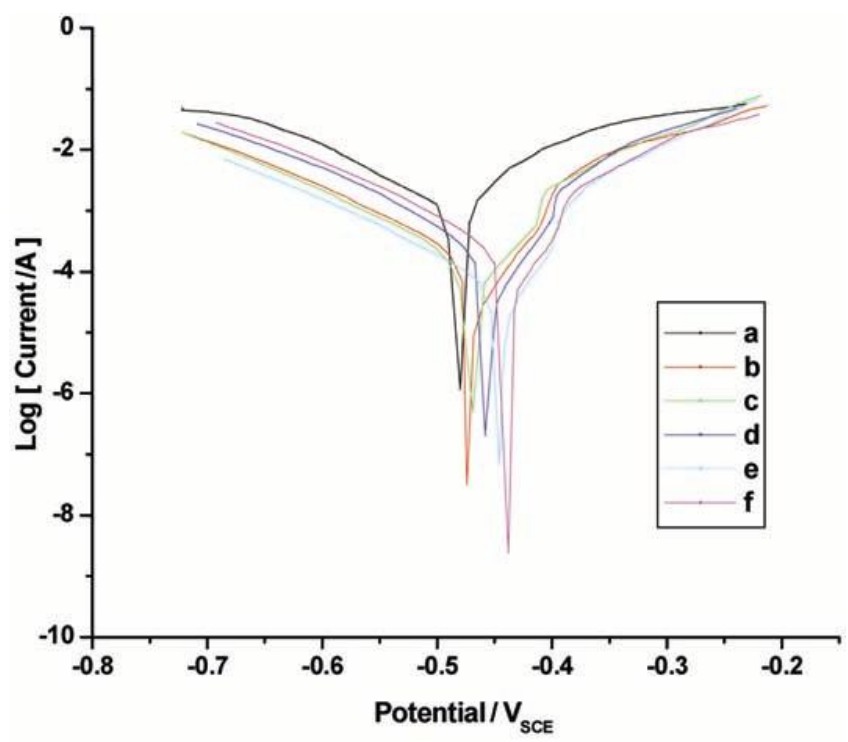

Figure 8. Polarization curves of mild steel in $1 \mathrm{M} \mathrm{H}_{2} \mathrm{SO}_{4}$ at $30^{\circ} \mathrm{C}$ in presence of different concentrations of DHBTPH: (a) 0 , (b) $0.230 \times 10^{-4}$, (c) $1.149 \times 10^{-4}$, (d) $2.299 \times 10^{-4}$, (e) $5.747 \times$ $10^{-4}$ and (f) $11.494 \times 10^{-4} \mathrm{M}$. 
Table 2. Electrochemical parameters and the corresponding inhibition efficiencies at various temperatures studied for mild steel in $1 \mathrm{M} \mathrm{HCl}$ containing different concentrations of DHBTPH.

\begin{tabular}{|c|c|c|c|c|c|}
\hline Temp. $\left({ }^{\circ} \mathrm{C}\right)$ & Inhibitor conc. $\left(10^{-4} \mathrm{M}\right)$ & $E_{\text {corr }}$ vs SCE $(\mathrm{mV})$ & $I_{\text {corr }}\left(\mu \mathrm{Acm}^{-2}\right)$ & $I E(\%)$ & $\theta$ \\
\hline 30 & $\begin{array}{c}1 \mathrm{M} \mathrm{HCl} \\
0.230 \\
1 \cdot 149 \\
2 \cdot 299 \\
5.747 \\
11.494\end{array}$ & $\begin{array}{l}-476 \\
-463 \\
-455 \\
-446 \\
-440 \\
-432\end{array}$ & $\begin{array}{l}570 \\
360 \\
287 \\
213 \\
140 \\
066\end{array}$ & $\begin{array}{c}- \\
36 \cdot 8 \\
49 \cdot 7 \\
62 \cdot 6 \\
75 \cdot 5 \\
88 \cdot 4\end{array}$ & $\begin{array}{c}- \\
0.368 \\
0.497 \\
0.626 \\
0.755 \\
0.884\end{array}$ \\
\hline 40 & $\begin{array}{c}1 \mathrm{M} \mathrm{HCl} \\
0 \cdot 230 \\
1 \cdot 149 \\
2 \cdot 299 \\
5 \cdot 747 \\
11.494\end{array}$ & $\begin{array}{l}-464 \\
-455 \\
-442 \\
-439 \\
-425 \\
-423\end{array}$ & $\begin{array}{l}912 \\
555 \\
440 \\
324 \\
208 \\
092\end{array}$ & $\begin{array}{c}- \\
39 \cdot 1 \\
51 \cdot 8 \\
64 \cdot 5 \\
77 \cdot 2 \\
89 \cdot 9\end{array}$ & $\begin{array}{c}- \\
0 \cdot 391 \\
0.518 \\
0 \cdot 645 \\
0.772 \\
0 \cdot 899\end{array}$ \\
\hline 50 & $\begin{array}{c}1 \mathrm{M} \mathrm{HCl} \\
0.230 \\
1.149 \\
2.299 \\
5.747 \\
11.494\end{array}$ & $\begin{array}{l}-456 \\
-447 \\
-441 \\
-434 \\
-425 \\
-412\end{array}$ & $\begin{array}{r}1767 \\
995 \\
779 \\
564 \\
348 \\
133\end{array}$ & $\begin{array}{c}- \\
43 \cdot 7 \\
55 \cdot 9 \\
68 \cdot 1 \\
80 \cdot 3 \\
92 \cdot 5\end{array}$ & $\begin{array}{c}- \\
0.437 \\
0.559 \\
0.681 \\
0.803 \\
0.925\end{array}$ \\
\hline 60 & $\begin{array}{c}1 \mathrm{M} \mathrm{HCl} \\
0 \cdot 230 \\
1 \cdot 149 \\
2 \cdot 299 \\
5 \cdot 747 \\
11.494\end{array}$ & $\begin{array}{l}-439 \\
-432 \\
-426 \\
-421 \\
-417 \\
-407\end{array}$ & $\begin{array}{r}2964 \\
1458 \\
1132 \\
806 \\
480 \\
169\end{array}$ & $\begin{array}{c}- \\
50 \cdot 8 \\
61 \cdot 6 \\
72 \cdot 2 \\
83 \cdot 5 \\
94 \cdot 3\end{array}$ & $\begin{array}{c}- \\
0.508 \\
0.616 \\
0.722 \\
0.835 \\
0.943\end{array}$ \\
\hline
\end{tabular}

where $I_{\text {corr }}$ and $I_{\text {corr(inh) }}$ are the corrosion current density values without and with inhibitor, respectively obtained by extrapolation of cathodic and anodic lines to the corrosion potentials.

The \% $I E$ values obtained from Tafel polarization measurements are tabulated in table 1 . These results are comparable with those calculated from weight-loss measurement and EIS measurements. But a little difference was observed. This difference can be attributed to the fact that the gravimetric method gives average corrosion rates, whereas the polarization method gives instantaneous corrosion rates (Muralidharan et al 1995; Foad and Sherbini 1999).

\subsection{Effect of temperature}

The effect of temperature on inhibition reaction is highly complex, because many changes may occur on the metal surface such as rapid etching, rupture, desorption of inhibitor and the decomposition and/or rearrangement of inhibitor. The effect of temperature on the rate of corrosion process was studied in different acid media without and with various concentrations of DHBTPH. The present study was aimed at exploring the activation energy of the corrosion process and thermodynamic functions of adsorption of DHBTPH. This was accomplished by investigating the temperature dependence of the corrosion current that was obtained using Tafel extrapolation method. The various electrochemical parameters were calculated from Tafel plots and summarized in tables $2-5$. The $\% I E$ and the degree of surface coverage $(\theta)$ for steel are also given in these tables. The degree of surface coverage $(\theta)$ was calculated from the following equation (Khamis 1990)

$$
\theta=\frac{I_{\text {corr }}-I_{\text {corr(inh })}}{I_{\text {corr }}},
$$

where $I_{\text {corr }}$ and $I_{\text {corr(inh) }}$ are the corrosion current density values in the absence and presence of DHBTPH.

The investigated DHBTPH showed inhibiting properties at all the studied temperatures $\left(30-60^{\circ} \mathrm{C}\right)$. The values of $\% I E$ for DHBTPH increased with increase in temperature (tables 2-5). Thus, DHBTPH efficiencies were temperature dependent. Similar observations were discussed by several researchers (Ammar and Khorafi 1973; Ivanov 1986).

The activation parameters for the corrosion process were calculated from Arrhenius-type plot according to the following equation

$$
I_{\text {corr }}=k \exp \left(-\frac{E_{\mathrm{a}}}{R T}\right),
$$

where $E_{\mathrm{a}}$ is the apparent activation corrosion energy, $R$ the universal gas constant and $k$ the Arrhenius pre-exponential constant. Arrhenius plots for the corrosion density of mild steel in the case of DHBTPH in $1 \mathrm{M} \mathrm{HCl}$ media are given in figure 9. Values of apparent activation energy of corrosion $\left(E_{\mathrm{a}}\right)$ for mild steel in $1 \mathrm{M} \mathrm{HCl}$ with the absence 
Table 3. Electrochemical parameters and the corresponding inhibition efficiencies at various temperatures studied for mild steel in $2 \mathrm{M} \mathrm{HCl}$ containing different concentrations of DHBTPH.

\begin{tabular}{|c|c|c|c|c|c|}
\hline Temp. $\left({ }^{\circ} \mathrm{C}\right)$ & Inhibitor conc. $\left(10^{-4} \mathrm{M}\right)$ & $E_{\text {corr }}$ vs SCE (mV) & $I_{\text {corr }}\left(\mu \mathrm{Acm}^{-2}\right)$ & $I E(\%)$ & $\theta$ \\
\hline 30 & $\begin{array}{c}2 \mathrm{M} \mathrm{HCl} \\
0 \cdot 230 \\
1 \cdot 149 \\
2 \cdot 299 \\
5 \cdot 747 \\
11 \cdot 494\end{array}$ & $\begin{array}{l}-470 \\
-463 \\
-457 \\
-455 \\
-439 \\
-429\end{array}$ & $\begin{array}{l}941 \\
575 \\
465 \\
349 \\
240 \\
146\end{array}$ & $\begin{array}{c}- \\
38 \cdot 9 \\
50 \cdot 6 \\
62 \cdot 9 \\
74 \cdot 5 \\
84 \cdot 5\end{array}$ & $\begin{array}{c}- \\
0.389 \\
0.506 \\
0.629 \\
0.745 \\
0.845\end{array}$ \\
\hline 40 & $\begin{array}{c}2 \mathrm{M} \mathrm{HCl} \\
0 \cdot 230 \\
1 \cdot 149 \\
2.299 \\
5 \cdot 747 \\
11.494\end{array}$ & $\begin{array}{l}-442 \\
-434 \\
-430 \\
-426 \\
-421 \\
-418\end{array}$ & $\begin{array}{r}1787 \\
1074 \\
861 \\
654 \\
443 \\
264\end{array}$ & $\begin{array}{c}- \\
39 \cdot 9 \\
51 \cdot 8 \\
63 \cdot 4 \\
75 \cdot 2 \\
85 \cdot 2\end{array}$ & $\begin{array}{c}- \\
0.399 \\
0.518 \\
0.634 \\
0.752 \\
0.852\end{array}$ \\
\hline 50 & $\begin{array}{c}2 \mathrm{M} \mathrm{HCl} \\
0 \cdot 230 \\
1 \cdot 149 \\
2 \cdot 299 \\
5.747 \\
11.494\end{array}$ & $\begin{array}{l}-433 \\
-427 \\
-423 \\
-418 \\
-415 \\
-409\end{array}$ & $\begin{array}{r}3856 \\
2244 \\
1828 \\
1361 \\
910 \\
536\end{array}$ & $\begin{array}{c}- \\
41 \cdot 8 \\
52 \cdot 6 \\
64 \cdot 7 \\
76 \cdot 4 \\
86 \cdot 1\end{array}$ & $\begin{array}{c}- \\
0.418 \\
0.526 \\
0.647 \\
0.764 \\
0.861\end{array}$ \\
\hline 60 & $\begin{array}{c}2 \mathrm{M} \mathrm{HCl} \\
0 \cdot 230 \\
1 \cdot 149 \\
2 \cdot 299 \\
5 \cdot 747 \\
11 \cdot 494\end{array}$ & $\begin{array}{l}-426 \\
-423 \\
-419 \\
-416 \\
-412 \\
-400\end{array}$ & $\begin{array}{r}5925 \\
3306 \\
2625 \\
1943 \\
1250 \\
693\end{array}$ & $\begin{array}{c}- \\
44 \cdot 2 \\
55 \cdot 7 \\
67 \cdot 2 \\
78 \cdot 9 \\
88 \cdot 3\end{array}$ & $\begin{array}{c}- \\
0.442 \\
0.557 \\
0.672 \\
0.789 \\
0.883\end{array}$ \\
\hline
\end{tabular}

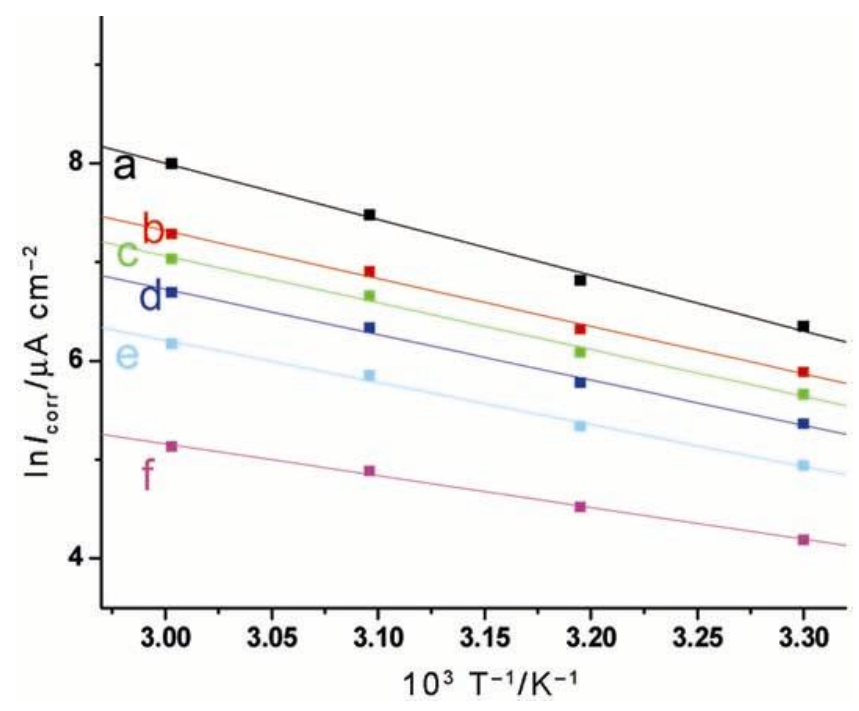

Figure 9. Arrhenius plots of corrosion $\ln I_{\text {corr }}$ vs $1 / T$ at different concentrations of DHBTPH: (a) $1 \mathrm{M} \mathrm{HCl}$, (b) $1 \mathrm{M} \mathrm{HCl}+$ $0.230 \times 10^{-4}$, (c) $1 \mathrm{M} \mathrm{HCl}+1.149 \times 10^{-4}$, (d) $1 \mathrm{M} \mathrm{HCl}+2.299 \times$ $10^{-4}$, (e) $1 \mathrm{M} \mathrm{HCl}+5.747 \times 10^{-4}$ and (f) $1 \mathrm{M} \mathrm{HCl}+11.494 \times$ $10^{-4} \mathrm{M}$.

and presence of various concentrations of DHBTPH were determined from the slope of $\ln \left(I_{\text {corr }}\right)$ vs $1 / T$ plots and tabulated in table 6. Similarly, $E_{\mathrm{a}}$ values for mild steel in different acid media with the absence and presence of various concentrations of DHBTPH were determined and tabulated in table 6. Inspection of the data shows that the activation energy is lower in the presence of inhibitors than in its absence. Moreover, the values obtained for DHBTPH in $2 \mathrm{M} \mathrm{HCl}$ are somewhat higher than those obtained for DHBTPH in $1 \mathrm{M} \mathrm{HCl}$ and confirm the fact that the inhibitor efficiency of DHBTPH in $2 \mathrm{M} \mathrm{HCl}$ is slightly lower than that in $1 \mathrm{M} \mathrm{HCl}$. Similar trend is observed between $0.5 \mathrm{M} \mathrm{H}_{2} \mathrm{SO}_{4}$ and $1 \mathrm{M} \mathrm{H}_{2} \mathrm{SO}_{4}$. The decrease in $E_{\mathrm{a}}$ with DHBTPH concentration (table 6) is typical of chemisorption.

An alternative formulation of Arrhenius equation is (Bentiss et al 2005)

$$
I_{\text {corr }}=\frac{R T}{N h} \exp \left(\frac{\Delta S_{\mathrm{a}}^{0}}{R}\right) \exp \left(-\frac{\Delta H_{\mathrm{a}}^{0}}{R T}\right),
$$

where $h$ is Planck's constant, $N$ the Avogadro's number, $\Delta S_{\mathrm{a}}^{0}$ the entropy of activation and $\Delta H_{\mathrm{a}}^{0}$ the enthalpy of activation. Figure 10 shows a plot of $\ln \left(I_{\text {corr }} / T\right)$ against $1 / T$ in the case of DHBTPH in $1 \mathrm{M} \mathrm{HCl}$. Similar behaviour is observed in the case of DHBTPH in $2 \mathrm{M} \mathrm{HCl}, 0.5 \mathrm{M}$ $\mathrm{H}_{2} \mathrm{SO}_{4}$ and $1 \mathrm{M} \mathrm{H}_{2} \mathrm{SO}_{4}$. Straight lines are obtained with a slope $\left(-\Delta H_{\mathrm{a}}^{0} / R\right)$ and an intercept $\left(\ln (R / N h)+\Delta S_{\mathrm{a}}^{0} / R\right)$ from which the values of $\Delta H_{\mathrm{a}}^{0}$ and $\Delta S_{\mathrm{a}}^{0}$ can be calculated (table $6)$. The positive signs of the enthalpies $\left(\Delta H_{\mathrm{a}}^{0}\right)$ reflect the endothermic nature of dissolution process of steel. Large and negative value of entropies $\left(\Delta S_{a}^{0}\right)$ imply that the activated complex in the rate determining step represents an association rather than a dissociation step, meaning that a 
Table 4. Electrochemical parameters and the corresponding inhibition efficiencies at various temperatures studied for mild steel in $0.5 \mathrm{M} \mathrm{H}_{2} \mathrm{SO}_{4}$ containing different concentrations of DHBTPH.

\begin{tabular}{|c|c|c|c|c|c|}
\hline Temp. $\left({ }^{\circ} \mathrm{C}\right)$ & Inhibitor conc. $\left(10^{-4} \mathrm{M}\right)$ & $E_{\text {corr }}$ vs SCE $(\mathrm{mV})$ & $I_{\text {corr }}\left(\mu \mathrm{Acm}^{-2}\right)$ & $I E(\%)$ & $\theta$ \\
\hline 30 & $\begin{array}{c}0.5 \mathrm{M} \mathrm{H}_{2} \mathrm{SO}_{4} \\
0.230 \\
1.149 \\
2.299 \\
5.747 \\
11.494\end{array}$ & $\begin{array}{l}-490 \\
-481 \\
-475 \\
-467 \\
-465 \\
-462\end{array}$ & $\begin{array}{r}1083 \\
412 \\
344 \\
249 \\
170 \\
057\end{array}$ & $\begin{array}{c}- \\
62 \cdot 0 \\
68 \cdot 2 \\
77 \cdot 0 \\
84 \cdot 3 \\
94 \cdot 7\end{array}$ & $\begin{array}{c}- \\
0.620 \\
0.682 \\
0.770 \\
0.843 \\
0.947\end{array}$ \\
\hline 40 & $\begin{array}{c}0.5 \mathrm{M} \mathrm{H}_{2} \mathrm{SO}_{4} \\
0.230 \\
1.149 \\
2.299 \\
5.747 \\
11.494\end{array}$ & $\begin{array}{l}-469 \\
-464 \\
-456 \\
-453 \\
-449 \\
-442\end{array}$ & $\begin{array}{r}1949 \\
692 \\
540 \\
401 \\
240 \\
076\end{array}$ & $\begin{array}{c}- \\
64 \cdot 5 \\
72 \cdot 3 \\
79 \cdot 4 \\
87 \cdot 7 \\
96 \cdot 1\end{array}$ & $\begin{array}{c}- \\
0.645 \\
0.723 \\
0.794 \\
0.877 \\
0.961\end{array}$ \\
\hline 50 & $\begin{array}{c}0.5 \mathrm{M} \mathrm{H}_{2} \mathrm{SO}_{4} \\
0.230 \\
1.149 \\
2.299 \\
5.747 \\
11.494\end{array}$ & $\begin{array}{l}-454 \\
-448 \\
-443 \\
-439 \\
-435 \\
-431\end{array}$ & $\begin{array}{r}5415 \\
1652 \\
1202 \\
899 \\
514 \\
146\end{array}$ & $\begin{array}{c}- \\
69 \cdot 5 \\
77 \cdot 8 \\
83 \cdot 4 \\
90 \cdot 5 \\
97 \cdot 3\end{array}$ & $\begin{array}{l}- \\
0.695 \\
0.778 \\
0.834 \\
0.905 \\
0.973\end{array}$ \\
\hline 60 & $\begin{array}{c}0.5 \mathrm{M} \mathrm{H}_{2} \mathrm{SO}_{4} \\
0.230 \\
1 \cdot 149 \\
2.299 \\
5.747 \\
11.494\end{array}$ & $\begin{array}{l}-448 \\
-445 \\
-440 \\
-434 \\
-428 \\
-419\end{array}$ & $\begin{array}{r}8556 \\
1506 \\
1258 \\
898 \\
530 \\
171\end{array}$ & $\begin{array}{c}- \\
82 \cdot 4 \\
85 \cdot 3 \\
89 \cdot 5 \\
93 \cdot 8 \\
98 \cdot 0\end{array}$ & $\begin{array}{c}- \\
0.824 \\
0 \cdot 853 \\
0.895 \\
0.938 \\
0.980\end{array}$ \\
\hline
\end{tabular}

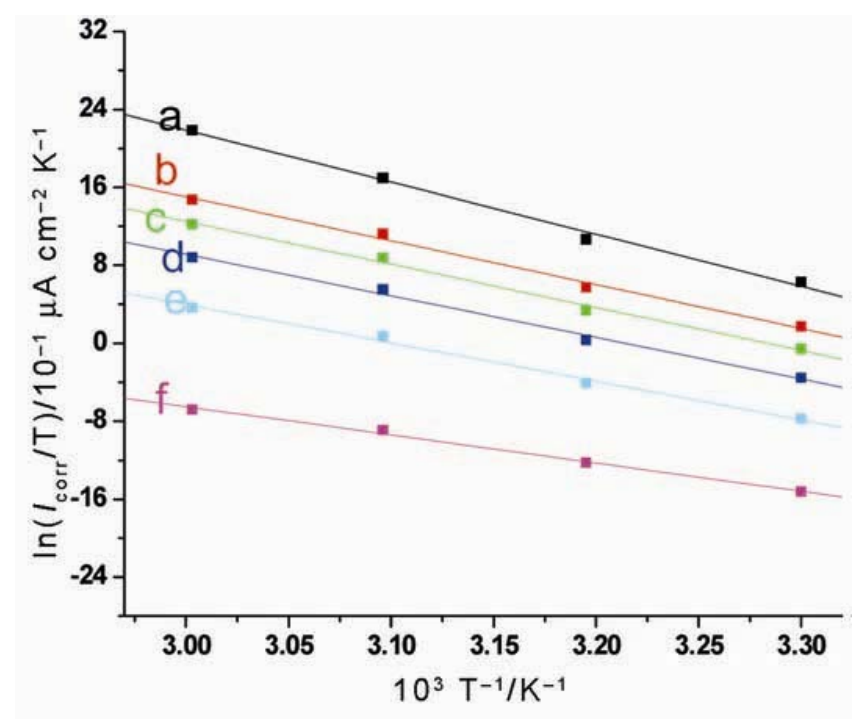

Figure 10. Arrhenius plots of $\ln \left(I_{\text {corr }} / T\right)$ vs $1 / T$ at different concentrations of DHBTPH: (a) $1 \mathrm{M} \mathrm{HCl}$, (b) $1 \mathrm{M} \mathrm{HCl}+$ $0.230 \times 10^{-4}$, (c) $1 \mathrm{M} \mathrm{HCl}+1 \cdot 149 \times 10^{-4}$, (d) $1 \mathrm{M} \mathrm{HCl}+2.299 \times$ $10^{-4}$, (e) $1 \mathrm{M} \mathrm{HCl}+5.747 \times 10^{-4}$ and (f) $1 \mathrm{M} \mathrm{HCl}+11.494 \times$ $10^{-4} \mathrm{M}$.

decrease in disordering takes place on going from reactants to the activated complex (Marsh 1988; Bentiss et al 2005).

\subsection{Application of adsorption isotherm}

In the temperature range studied, the best correlation between the experimental results and the isotherm functions was obtained using Langmuir adsorption isotherm. The Langmuir isotherm for monolayer chemisorption is given by the following equation (Agrawal and Namboodhiri 1990)

$$
\frac{\theta}{1-\theta}=K C_{\mathrm{inh}}
$$

Rearranging this equation gives

$$
\frac{C_{\mathrm{inh}}}{\theta}=\frac{1}{K}+C_{\mathrm{inh}},
$$

where $\theta$ is the degree of surface coverage, $C_{\text {inh }}$ the inhibitor concentration in the electrolyte and $K$ the equilibrium constant of the adsorption process. The correlation coefficient $\left(R^{2}\right)$ was used to choose the isotherm that best fit experimental data (table 7). The plot of $C_{\mathrm{inh}} / \theta$ against $C_{\mathrm{inh}}$ of DHBTPH in $1 \mathrm{M} \mathrm{HCl}$ gives a straight line as shown in figure 11. Similar plots were obtained in case of DHBTPH in $2 \mathrm{M} \mathrm{HCl}, 0.5 \mathrm{M} \mathrm{H}_{2} \mathrm{SO}_{4}$ and $1 \mathrm{M} \mathrm{H}_{2} \mathrm{SO}_{4}$. It is found that all the linear correlation coefficients are close to 1. These isotherms conform to Langmuir's type, suggesting monolayer chemisorption of DHBTPH. From the in- 
Table 5. Electrochemical parameters and the corresponding inhibition efficiencies at various temperatures studied for mild steel in $1 \mathrm{M} \mathrm{H}_{2} \mathrm{SO}_{4}$ containing different concentrations of DHBTPH.

\begin{tabular}{|c|c|c|c|c|c|}
\hline Temp. $\left({ }^{\circ} \mathrm{C}\right)$ & Inhibitor conc. $\left(10^{-4} \mathrm{M}\right)$ & $E_{\text {corr }}$ vs SCE $(\mathrm{mV})$ & $I_{\text {corr }}\left(\mu \mathrm{Acm}^{-2}\right)$ & $I E(\%)$ & $\theta$ \\
\hline 30 & $\begin{array}{c}1 \mathrm{M} \mathrm{H}_{2} \mathrm{SO}_{4} \\
0.230 \\
1 \cdot 149 \\
2.299 \\
5.747 \\
11.494\end{array}$ & $\begin{array}{l}-480 \\
-474 \\
-469 \\
-458 \\
-446 \\
-438\end{array}$ & $\begin{array}{r}2138 \\
915 \\
759 \\
603 \\
447 \\
291\end{array}$ & $\begin{array}{c}- \\
57 \cdot 2 \\
64 \cdot 5 \\
71 \cdot 8 \\
79 \cdot 1 \\
86 \cdot 4\end{array}$ & $\begin{array}{c}- \\
0.572 \\
0.645 \\
0.718 \\
0.791 \\
0.864\end{array}$ \\
\hline 40 & $\begin{array}{c}1 \mathrm{M} \mathrm{H}_{2} \mathrm{SO}_{4} \\
0.230 \\
1 \cdot 149 \\
2.299 \\
5.747 \\
11.494\end{array}$ & $\begin{array}{l}-455 \\
-451 \\
-447 \\
-441 \\
-432 \\
-420\end{array}$ & $\begin{array}{r}4489 \\
1818 \\
1499 \\
1181 \\
862 \\
543\end{array}$ & $\begin{array}{c}- \\
59 \cdot 5 \\
66 \cdot 6 \\
73 \cdot 7 \\
80 \cdot 8 \\
87 \cdot 9\end{array}$ & $\begin{array}{c}- \\
0.595 \\
0 \cdot 666 \\
0.737 \\
0 \cdot 808 \\
0 \cdot 879\end{array}$ \\
\hline 50 & $\begin{array}{c}1 \mathrm{M} \mathrm{H}_{2} \mathrm{SO}_{4} \\
0.230 \\
1 \cdot 149 \\
2.299 \\
5.747 \\
11.494\end{array}$ & $\begin{array}{l}-446 \\
-438 \\
-435 \\
-425 \\
-420 \\
-412\end{array}$ & $\begin{array}{r}11970 \\
4441 \\
3627 \\
2813 \\
1999 \\
1185\end{array}$ & $\begin{array}{c}- \\
62 \cdot 9 \\
69 \cdot 7 \\
76 \cdot 5 \\
83 \cdot 3 \\
90 \cdot 1\end{array}$ & $\begin{array}{c}- \\
0.629 \\
0.697 \\
0 \cdot 765 \\
0 \cdot 833 \\
0.901\end{array}$ \\
\hline 60 & $\begin{array}{c}1 \mathrm{M} \mathrm{H}_{2} \mathrm{SO}_{4} \\
0.230 \\
1 \cdot 149 \\
2.299 \\
5.747 \\
11.494\end{array}$ & $\begin{array}{l}-443 \\
-435 \\
-430 \\
-421 \\
-414 \\
-405\end{array}$ & $\begin{array}{r}17314 \\
5610 \\
4536 \\
3463 \\
2389 \\
1316\end{array}$ & $\begin{array}{c}- \\
67 \cdot 6 \\
73 \cdot 8 \\
80 \cdot 0 \\
86 \cdot 2 \\
92 \cdot 4\end{array}$ & $\begin{array}{c}- \\
0.676 \\
0.738 \\
0.800 \\
0 \cdot 862 \\
0.924\end{array}$ \\
\hline
\end{tabular}

Table 6. The value of activation parameters, $E_{\mathrm{a}}, \Delta H_{\mathrm{a}}^{0}$ and $\Delta S_{\mathrm{a}}^{0}$ for mild steel in acid media in the absence and presence of different concentrations of DHBTPH.

\begin{tabular}{|c|c|c|c|}
\hline Inhibitor conc. $\left(10^{-4} \mathrm{M}\right)$ & $E_{\mathrm{a}}\left(\mathrm{kJ} \mathrm{mol}^{-1}\right)$ & $\Delta H_{\mathrm{a}}^{0}\left(\mathrm{~kJ} \mathrm{~mol}^{-1}\right)$ & $\Delta S_{\mathrm{a}}^{0}\left(\mathrm{~J} \mathrm{~mol}^{-1} \mathrm{~K}^{-1}\right)$ \\
\hline $1 \mathrm{M} \mathrm{HCl}$ & $46 \cdot 99$ & $44 \cdot 35$ & $-46 \cdot 31$ \\
\hline $0 \cdot 230$ & $40 \cdot 09$ & 37.45 & $-72 \cdot 71$ \\
\hline $1 \cdot 149$ & $39 \cdot 38$ & $36 \cdot 74$ & $-76 \cdot 94$ \\
\hline $2 \cdot 299$ & $38 \cdot 14$ & $35 \cdot 50$ & $-83 \cdot 46$ \\
\hline $5 \cdot 747$ & 35.43 & 32.79 & -95.89 \\
\hline 11.494 & $26 \cdot 70$ & 24.06 & $-130 \cdot 81$ \\
\hline $2 \mathrm{M} \mathrm{HCl}$ & $52 \cdot 84$ & $50 \cdot 21$ & $-22 \cdot 38$ \\
\hline $0 \cdot 230$ & $50 \cdot 31$ & $47 \cdot 67$ & $-34 \cdot 80$ \\
\hline $1 \cdot 149$ & $49 \cdot 99$ & $47 \cdot 35$ & $-37 \cdot 61$ \\
\hline $2 \cdot 299$ & $49 \cdot 47$ & $46 \cdot 83$ & $-41 \cdot 63$ \\
\hline $5 \cdot 747$ & $47 \cdot 71$ & $45 \cdot 07$ & $-50 \cdot 53$ \\
\hline $11 \cdot 494$ & $45 \cdot 31$ & $42 \cdot 67$ & $-62 \cdot 52$ \\
\hline $0.5 \mathrm{M} \mathrm{H}_{2} \mathrm{SO}_{4}$ & $60 \cdot 63$ & $57 \cdot 99$ & $4 \cdot 06$ \\
\hline $0 \cdot 230$ & $40 \cdot 24$ & $37 \cdot 60$ & $-70 \cdot 36$ \\
\hline $1 \cdot 149$ & $39 \cdot 50$ & $36 \cdot 86$ & $-74 \cdot 61$ \\
\hline $2 \cdot 299$ & $39 \cdot 27$ & $36 \cdot 63$ & -77.93 \\
\hline $5 \cdot 747$ & $35 \cdot 18$ & $32 \cdot 54$ & -94.93 \\
\hline 11.494 & $33 \cdot 02$ & $30 \cdot 38$ & $-111 \cdot 34$ \\
\hline $1 \mathrm{M} \mathrm{H}_{2} \mathrm{SO}_{4}$ & $61 \cdot 03$ & $58 \cdot 39$ & $11 \cdot 6$ \\
\hline $0 \cdot 230$ & $53 \cdot 34$ & $50 \cdot 70$ & $-20 \cdot 68$ \\
\hline $1 \cdot 149$ & $52 \cdot 62$ & $49 \cdot 98$ & $-24 \cdot 59$ \\
\hline $2 \cdot 299$ & 51.49 & $48 \cdot 85$ & $-30 \cdot 20$ \\
\hline $5 \cdot 747$ & $49 \cdot 48$ & $46 \cdot 84$ & $-39 \cdot 30$ \\
\hline 11.494 & $44 \cdot 79$ & $42 \cdot 15$ & $-58 \cdot 24$ \\
\hline
\end{tabular}


Table 7. Thermodynamic parameters for DHBTPH adsorption on mild steel in different acid media and temperatures.

\begin{tabular}{|c|c|c|c|c|c|c|}
\hline Acid media & Temp $\left({ }^{\circ} \mathrm{C}\right)$ & $K\left(\mathrm{M}^{-1}\right)$ & $R^{2}$ & $\Delta G_{\text {ads }}^{0}\left(\mathrm{~kJ} \mathrm{~mol}^{-1}\right)$ & $\Delta H_{\mathrm{ads}}^{0}\left(\mathrm{~kJ} \mathrm{~mol}^{-1}\right)$ & $\Delta S_{\mathrm{ads}}^{0}\left(\mathrm{~J} \mathrm{~mol}^{-1} \mathrm{~K}^{-1}\right)$ \\
\hline $1 \mathrm{M} \mathrm{HCl}$ & $\begin{array}{l}30 \\
40 \\
50 \\
60\end{array}$ & $\begin{array}{l}10525 \\
11290 \\
12950 \\
16331\end{array}$ & $\begin{array}{l}0.996 \\
0.997 \\
0.997 \\
0.998\end{array}$ & $\begin{array}{l}-33 \cdot 45 \\
-34.74 \\
-36 \cdot 22 \\
-37.98\end{array}$ & $12 \cdot 31$ & $150 \cdot 65$ \\
\hline $2 \mathrm{M} \mathrm{HCl}$ & $\begin{array}{l}30 \\
40 \\
50 \\
60\end{array}$ & $\begin{array}{l}12021 \\
12368 \\
12933 \\
14185\end{array}$ & $\begin{array}{c}0.998 \\
0.998 \\
0 \cdot 998 \\
0.998\end{array}$ & $\begin{array}{l}-33 \cdot 79 \\
-34 \cdot 98 \\
-36 \cdot 22 \\
-37 \cdot 59\end{array}$ & $4 \cdot 58$ & $126 \cdot 50$ \\
\hline $0 \cdot 5 \mathrm{M} \mathrm{H}_{2} \mathrm{SO}_{4}$ & $\begin{array}{l}30 \\
40 \\
50 \\
60\end{array}$ & $\begin{array}{l}21207 \\
24857 \\
32135 \\
56701\end{array}$ & $\begin{array}{l}0.998 \\
0.999 \\
0.999 \\
1.000\end{array}$ & $\begin{array}{l}-35 \cdot 22 \\
-36 \cdot 80 \\
-38 \cdot 66 \\
-41.43\end{array}$ & $27 \cdot 15$ & 204.97 \\
\hline $1 \mathrm{M} \mathrm{H}_{2} \mathrm{SO}_{4}$ & $\begin{array}{l}30 \\
40 \\
50 \\
60\end{array}$ & $\begin{array}{l}22413 \\
24135 \\
26916 \\
31841\end{array}$ & $\begin{array}{l}0.999 \\
0.999 \\
0.999 \\
0.999\end{array}$ & $\begin{array}{l}-35 \cdot 36 \\
-36 \cdot 72 \\
-38 \cdot 19 \\
-39 \cdot 83\end{array}$ & $9 \cdot 81$ & $148 \cdot 86$ \\
\hline
\end{tabular}
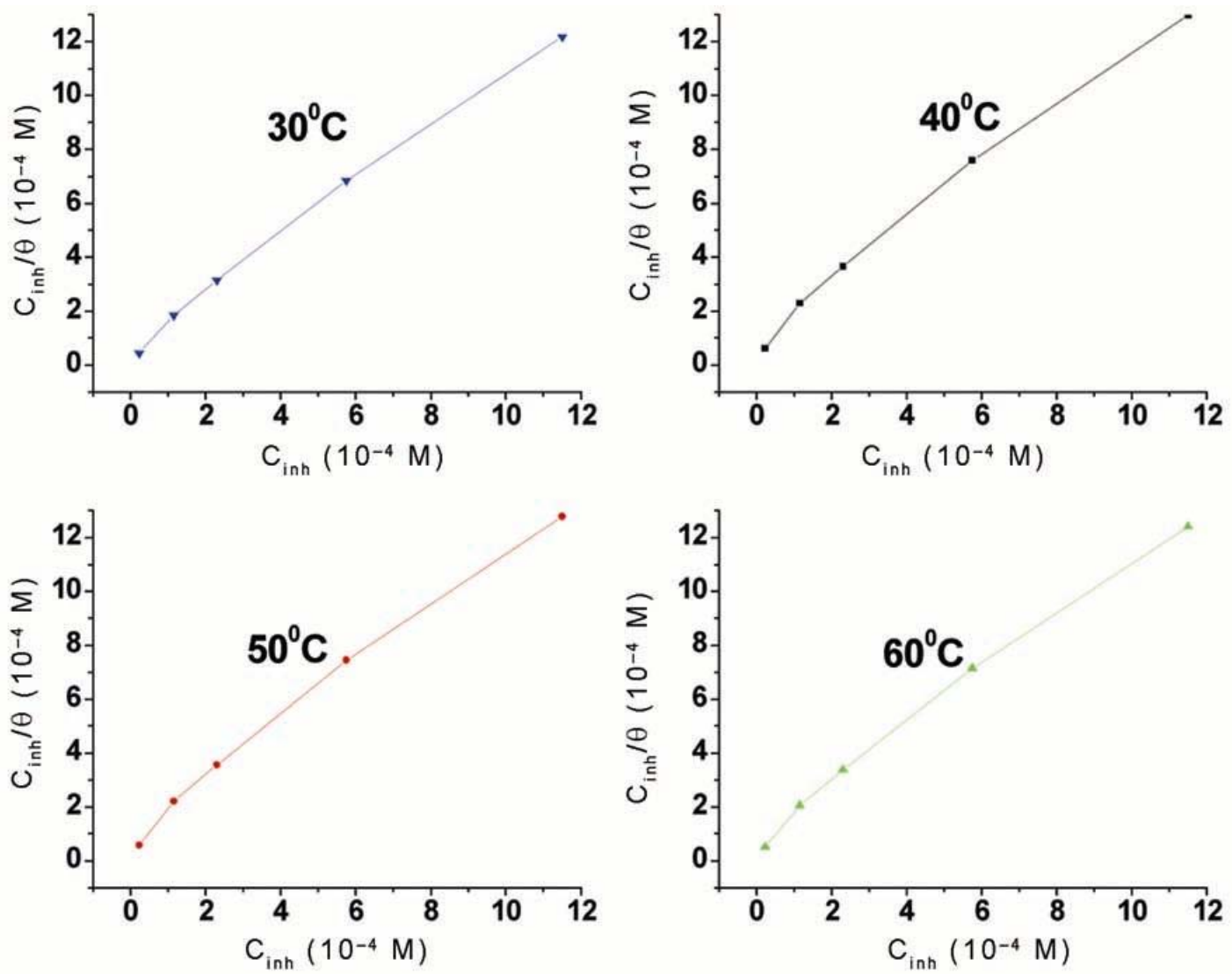

Figure 11. Langmuir's adsorption isotherms for DHBTPH on the surface of mild steel in $1 \mathrm{M} \mathrm{HCl}$ at different temperatures.

tercepts of the straight lines, $C_{\text {inh }} / \theta$-axis, $K$ values were calculated and are given in table 7.

The constant of adsorption, $K$, is related to the standard free energy of adsorption, $\Delta G_{\mathrm{ads}}^{0}$, with the following equation:

$$
K=\frac{1}{55 \cdot 5} \exp \left(\frac{-\Delta G_{\mathrm{ads}}^{0}}{R T}\right)
$$

The value, $55 \cdot 5$, in the above equation is the concentration of water in solution in $\mathrm{mol} \mathrm{L}^{-1}$ (Bouklah et al 2006). From the above equation the standard free of adsorption $\left(\Delta G_{\text {ads }}^{0}\right)$ can be calculated.

A plot of $\left(\Delta G_{\text {ads }}^{0}\right)$ vs $T$ in figure 12 gave the heat of adsorption $\left(\Delta H_{\mathrm{ads}}^{0}\right)$ and the standard entropy $\left(\Delta S_{\mathrm{ads}}^{0}\right)$ according to the thermodynamic basic equation, $\Delta G_{\mathrm{ads}}^{0}=\Delta H_{\mathrm{ads}}^{0}-$ $T \Delta S_{\text {ads }}^{0}$. Figure 12 clearly shows the good dependence of 
$\Delta G_{\text {ads }}^{0}$ on $T$, indicating the good correlation among thermodynamic parameters. The thermodynamic data obtained from DHBTPH using the adsorption isotherm are depicted in table 7. The negative value of $\Delta G_{\text {ads }}^{0}$ ensure the spontaneity of the adsorption process and stability of the adsorbed layer on the steel surface. The calculated $\Delta G_{\text {ads }}^{0}$ values are closer to $-40 \mathrm{~kJ} \mathrm{~mol}^{-1}$ (table 7) indicating that the adsorption mechanism of the DHBTPH on steel in studied acid media was typical of chemisorption (Yurt et al 2005). The unshared electron pairs in sulphur, nitrogen as well as in oxygen may interact with $d$-orbitals of steel to provide a protective chemisorbed film (Bentiss et al 2000).

The values of thermodynamic parameter for the adsorption of inhibitors can provide valuable information

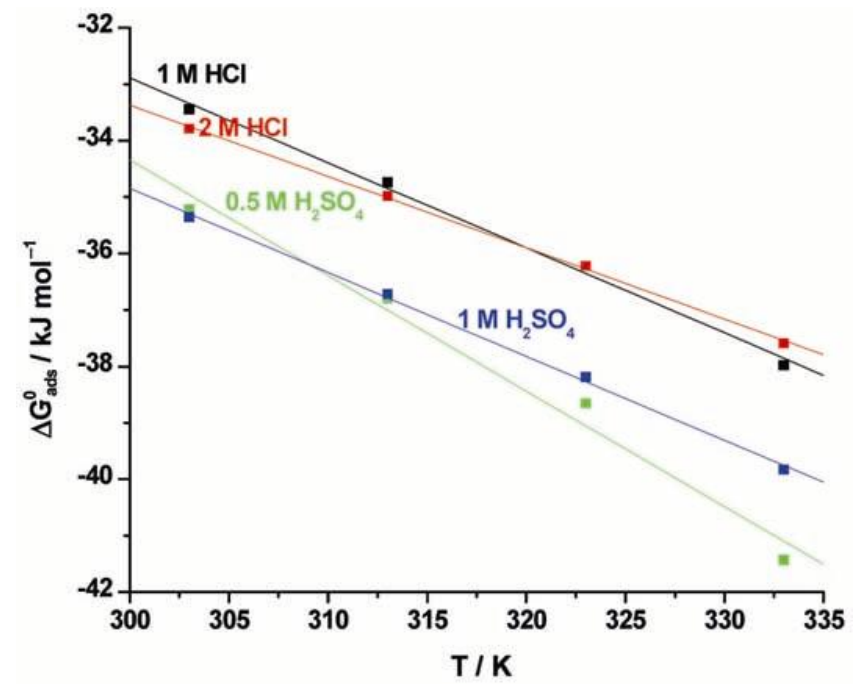

Figure 12. Variation of $\Delta G_{\mathrm{ads}}^{0}$ vs $T$ on mild steel in acid media containing DHBTPH.

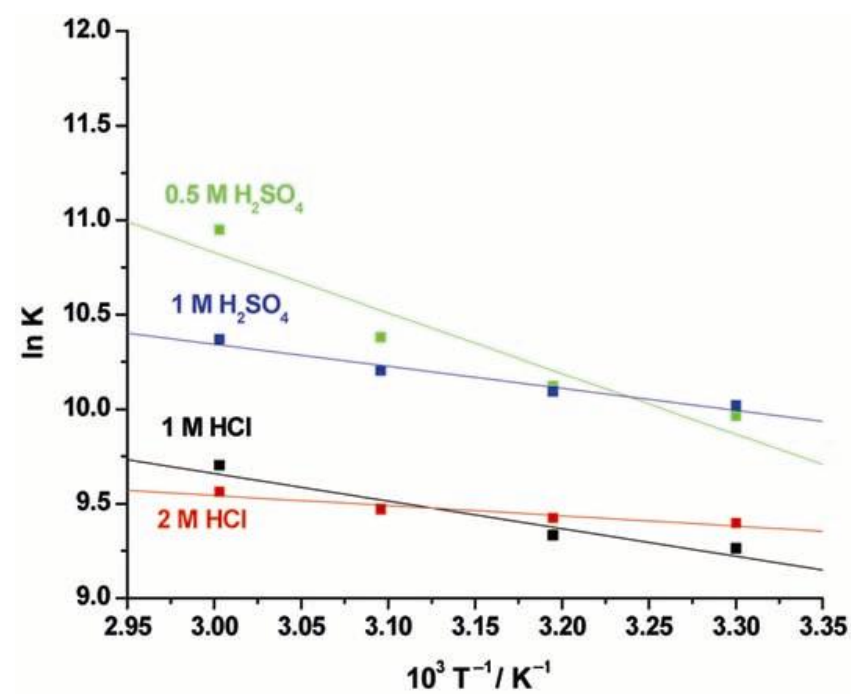

Figure 13. Van't Hoff plots for the mild steel in DHBTPH in acid media. about the mechanism of corrosion inhibition. In the presented case, the calculated values of $\Delta H_{\text {ads }}^{0}$ for the adsorption of DHBTPH in $1 \mathrm{M} \mathrm{HCl}, 2 \mathrm{M} \mathrm{HCl}, 0.5 \mathrm{M} \mathrm{H}_{2} \mathrm{SO}_{4}$ and $1 \mathrm{M} \mathrm{H}_{2} \mathrm{SO}_{4}$ is $12.31,4.58,27.15$ and $9.81 \mathrm{~kJ} \mathrm{~mol}^{-1}$, respectively, indicating that this inhibitor can be considered chemically adsorbed (Durnie et al 1999). The high value of $\Delta H_{\text {ads }}^{0}$ in the case of DHBTPH in $1 \mathrm{M} \mathrm{HCl}$ and $0.5 \mathrm{M}$ $\mathrm{H}_{2} \mathrm{SO}_{4}$ indicated that this is more strongly adsorbed on the steel surface. This is in good agreement with the results obtained from weight-loss, EIS and Tafel measurements.

The $\Delta S_{\mathrm{ads}}^{0}$ values in the presence of DHBTPH in $1 \mathrm{M}$ $\mathrm{HCl}, 2 \mathrm{M} \mathrm{HCl}, 0.5 \mathrm{M} \mathrm{H}_{2} \mathrm{SO}_{4}$ and $1 \mathrm{M} \mathrm{H}_{2} \mathrm{SO}_{4}$ are large and positive, meaning that an increase in disordering takes place in going from reactants to the metal-adsorbed species reaction complex (Banerjee and Malhotra 1992).

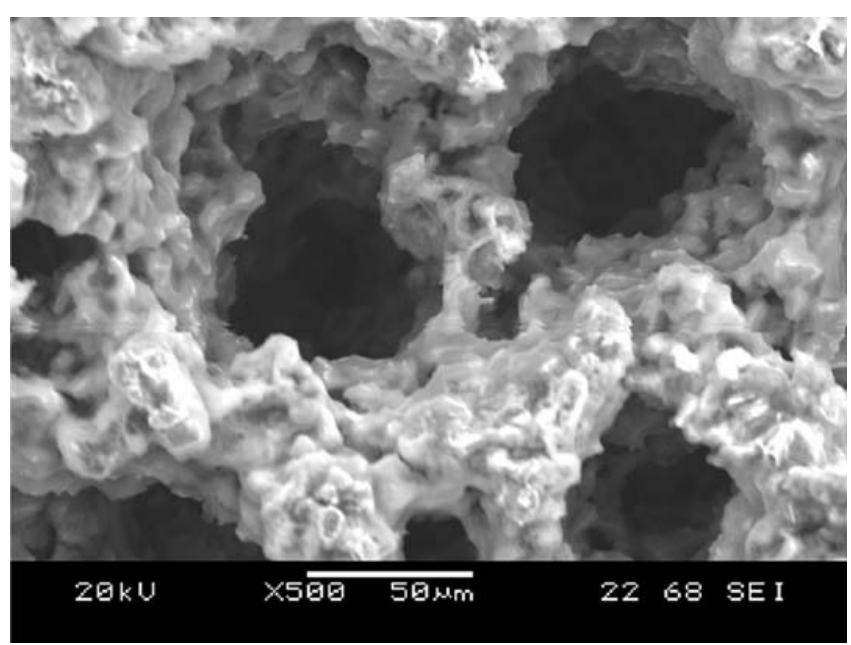

Figure 14. SEM image of surface of mild steel after immersion for $24 \mathrm{~h}$ in $1 \mathrm{M} \mathrm{HCl}$ at $30^{\circ} \mathrm{C}$ (Magnification, X500).

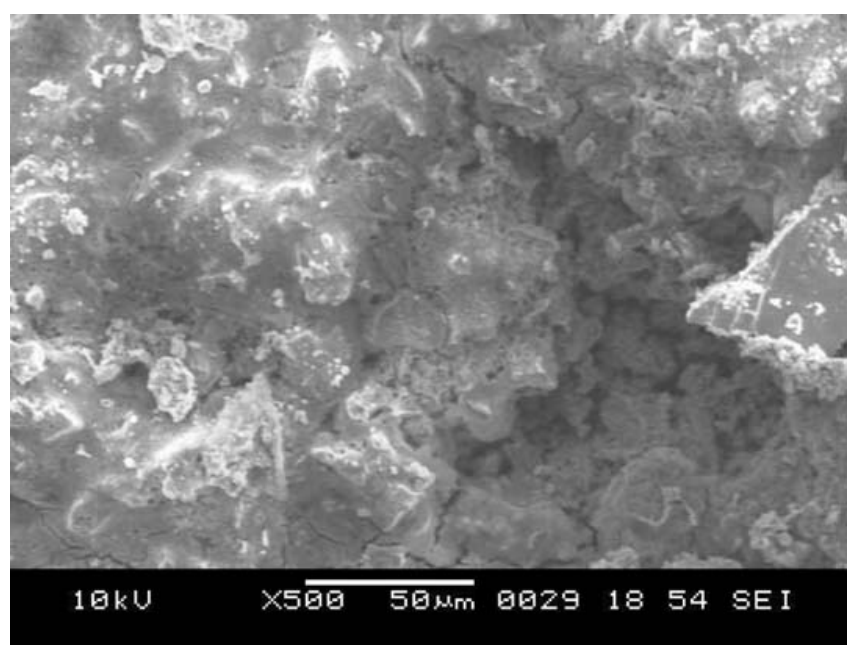

Figure 15. SEM image of surface of mild steel after immersion for $24 \mathrm{~h}$ in $0.5 \mathrm{M} \mathrm{H}_{2} \mathrm{SO}_{4}$ at $30^{\circ} \mathrm{C}$ (Magnification, X500). 


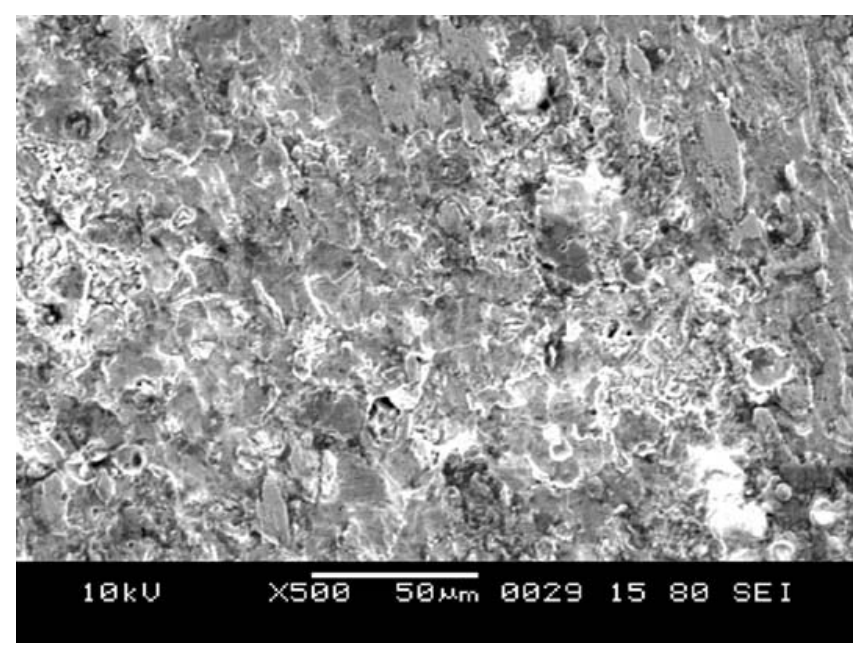

Figure 16. SEM image of surface of mild steel after immersion for $24 \mathrm{~h}$ in $1 \mathrm{M} \mathrm{HCl}$ at $30^{\circ} \mathrm{C}$ in presence of $11.494 \times$ $10^{-4} \mathrm{M}$. DHBTPH (Magnification, X500).

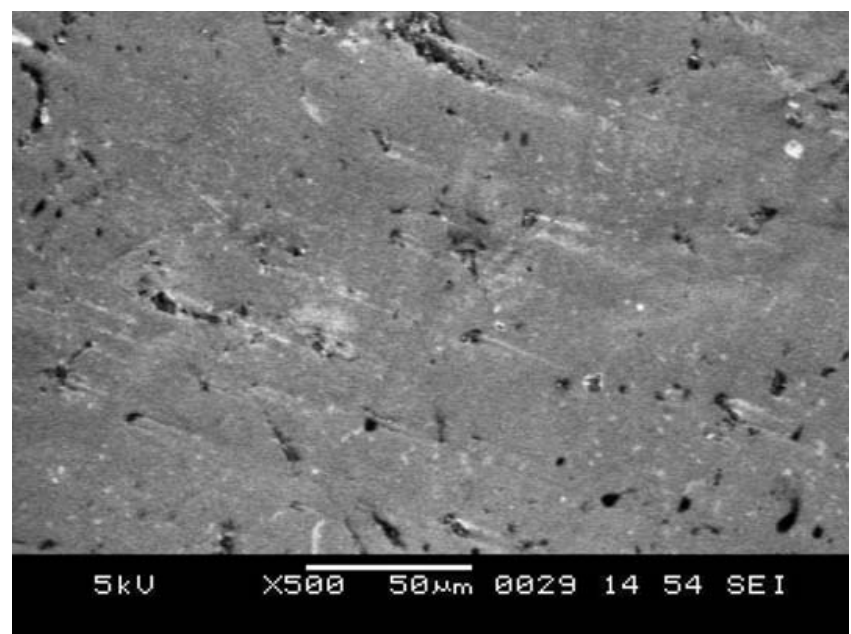

Figure 17. SEM image of surface of mild steel after immersion for $24 \mathrm{~h}$ in $0.5 \mathrm{M} \mathrm{H} \mathrm{SO}_{4}$ at $30^{\circ} \mathrm{C}$ in presence of $11.494 \times 10^{-4} \mathrm{M}$ DHBTPH (Magnification, X500).

The following integrated version of the Van't Hoff equation can also be used to obtain $\Delta H_{\mathrm{ads}}^{0}$ values (Tang et al 2006)

$$
\ln K=-\frac{\Delta H_{\mathrm{ads}}^{0}}{R T}+\text { constant. }
$$

Figure 13 shows the plot of $\ln K$ vs $1 / T$ for DHBTPH in $1 \mathrm{M} \mathrm{HCl}$ which gives straight lines with slopes $\left(-\Delta H_{\mathrm{ads}}^{0} / R\right)$ and intercepts $\left(\Delta S_{\mathrm{ads}}^{0} / R+\ln 1 / 55 \cdot 5\right)$. Similar plots were obtained in case of DHBTPH in different acid media. The calculated $\Delta H_{\text {ads }}^{0}$ values using the Van't Hoff equation are $12 \cdot 12,4 \cdot 51,26.68$ and $9.70 \mathrm{~kJ} \mathrm{~mol}^{-1}$ for $1 \mathrm{M} \mathrm{HCl}, 2 \mathrm{M} \mathrm{HCl}$, $0.5 \mathrm{M} \mathrm{H}_{2} \mathrm{SO}_{4}$ and $1 \mathrm{M} \mathrm{H}_{2} \mathrm{SO}_{4}$, respectively, confirming the endothermic behaviour of the adsorption of these inhibitors on the steel surface, therefore, the chemisorptions process. Values of $\Delta H_{\text {ads }}^{0}$ obtained by both the methods are in good agreement. Moreover, the deduced $\Delta S_{\text {ads }}^{0}$ values of $150.05,126.26,203.47$ and $148.50 \mathrm{~J} \mathrm{~mol}^{-1} \mathrm{~K}^{-1}$ for DHBTPH in $1 \mathrm{M} \mathrm{HCl}, 2 \mathrm{M} \mathrm{HCl}, 0.5 \mathrm{M} \mathrm{H}_{2} \mathrm{SO}_{4}$ and $1 \mathrm{M}$ $\mathrm{H}_{2} \mathrm{SO}_{4}$, respectively are very close to that obtained in table 7 .

\subsection{Scanning electron microscopy}

The SEM micrographs of the corroded mild steel in the presence of $1 \mathrm{M} \mathrm{HCl}$ and $0.5 \mathrm{M} \mathrm{H}_{2} \mathrm{SO}_{4}$ solutions are shown in figures 14 and 15 . The faceting seen in the figures was a result of pits formed due to the exposure of mild steel to the acid. The influences of the inhibitor addition (11.494 $\times$ $10^{-4} \mathrm{M}$ ) on the mild steel in $1 \mathrm{M} \mathrm{HCl}$ and $0.5 \mathrm{M} \mathrm{H}_{2} \mathrm{SO}_{4}$ solutions are shown in figures 16 and 17. The faceting observed in figures 14 and 15 disappeared and the surface was free from pits and it was smooth. It can be concluded from figures 14-17 that corrosion does not occur in presence of inhibitor and hence corrosion was inhibited strongly when the inhibitor was present in the acid media (Keera 2003).

\section{Conclusions}

(I) Reasonably good agreement was observed between the data obtained from the weight-loss, electrochemical impedance spectroscopy and potentiodynamic polarization techniques.

(II) DHBTPH suppressed the anodic reaction to greater extents than the cathodic one; these observations suggest that DHBTPH behaves mainly as anodic inhibitor in the studied acid. The inhibition efficiency trend in different acid media was in the decreasing order $0.5 \mathrm{M} \mathrm{H}_{2} \mathrm{SO}_{4}>$ $1 \mathrm{M} \mathrm{HCl}>1 \mathrm{M} \mathrm{H}_{2} \mathrm{SO}_{4}>2 \mathrm{M} \mathrm{HCl}$.

(III) $\% I E$ of DHBTPH was temperature-dependent and their addition led to a decrease of the activation corrosion energy in all the studied acid media.

(IV) The thermodynamics parameters reveal that the inhibition of corrosion by DHBTPH is due to the formation of a chemisorbed film on the metal surface.

(V) Adsorption of DHBTPH was found to follow the Langmuir's adsorption isotherm.

\section{Acknowledgements}

The authors are thankful to the Head, Chemistry Department, NITK and Head, SeQuent Scientific Ltd., Mangalore, for their encouragement and necessary laboratory facilities.

\section{References}

Abd El-Rehim S S, Ibrahim M A M and Khaled K F 1999 J. Appl. Electrochem. 29593 
Agrawal R and Namboodhiri T K G 1990 Corros. Sci. 3037 Allais, Andre and Meier Jean 1969 (Roussel-UCLAF) Ger. Offen. 1815467

Ammar I A and Khorafi F M El 1973 Werkst. Korros. 24702

Banerjee G and Malhotra S N 1992 Corrosion 4810

Bentiss F, Traisnel M and Lagrenee M 2000 Corros. Sci. 42 127

Bentiss F, Traisnel M and Lagrenee M $2001 \mathrm{~J}$. Appl. Electrochem. 3141

Bentiss F, Lagrenee M, Mehdi B, Mernari B, Traisnel M and Vezin H 2002 Corrosion 58399

Bentiss F, Lebrini M and Lagrenee M 2005 Corros. Sci. 47 2915

Bouklah M, Hammouti B, Lagrenee M and Bentiss F 2006 Corros. Sci. 482831

Durnie W, Marco R D, Jefferson A and Kinsella A B $1999 \mathrm{~J}$. Electrochem. Soc. 1461751

Emregul Kaan C, Kurtaran Raif and Atakol Orhan 2003 Corros. Sci. 452803

Foad E E and Sherbini E1 1999 Mater. Chem. Phys. 60286

Ivanov E S 1986 Inhibitors for metal corrosion in acid media (Moscow: Metallurgy)

Juttner K 1990 Electrochim. Acta 351501

Keera S T 2003 J. Sci. Ind. Res. 62188

Khaled F, Babic-Samardzija K and Hackerman N 2004 J. Appl. Electrochem. 34697

Khamis E 1990 Corrosion 466

Marsh J 1988 Advanced organic chemistry (New Delhi: Wiley Eastern) 3rd ed
McCafferty E and Hackerman N 1972 J. Electrochem. Soc. 119 146

Mehaute A H and Grepy G 1989 Solid State Ionics 9-10 17

Mora-Mendoza J L, Chacon-Nava J G, Zavala-Olivares G, Gonzalez-Nunez M A and Turgoose S 2002 Corros. Eng. 58 608

Muralidharan S, Quraishi M A and Iyer S V K 1995 Corros. Sci. 371739

Popova A, Christov M, Raicheva S and Sokolova E 2004 Corros. Sci. 461333

Quraishi M A and Jamal D 2002 J. Appl. Electrochem. 32425

Quraishi M A, Jamal D and Singh R N 2002 Corrosion 58 201

Reinhard G and Rammet U 1985 in Proceedings 6th European symposium on corrosion inhibitors (Ferrara: Ann. University) p. 831

Rengamani S, Muralidharan S, Anbu Kulamdainathan M and Venkatakrishna Iyer S 1994 J. Appl. Electrochem. 24355

Stoynov Z B, Grafov B M, Savova-Stoynova B and Elkin V V 1991 Electrochemical impedance (Moscow: Nauka)

Tang Libin, Li Xueming and Li Lin 2006 Mater. Chem. Phys. 97301

Vishwanatham S and Anil Kumar 2005 Corros. Rev. 23181

Wang Hui-Long, Liu Rui-Bin and Xin Jian 2004 Corros. Sci. 462455

Yurt A, Bereket G, Kivrak A, Balaban A and Erk B $2005 \mathrm{~J}$. Appl. Electrochem. 351025

Zor Sibel, Dogan Pinar and Yazici Birgul 2005 Corros. Rev. 23 217 